\title{
النموذج المعرفي لنقد الأديان عند الفاروقي
}

\section{*}

بالال التليدي

ملخص

تتعرض الورقة للأسس المنهجية التي اشترطها إسماعيل الفاروقي للتأسيس لنموذجه المعرفي؛ فاشترط مطلبين أساسيين : أولمما الانخراط داخل الظاهرة الدينية واكتشاف منطقها، وثانيهما وضع مبادئ لفهم الدين وتقويمه. ويتعلق

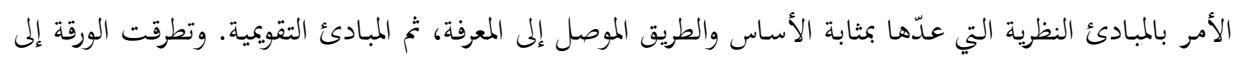

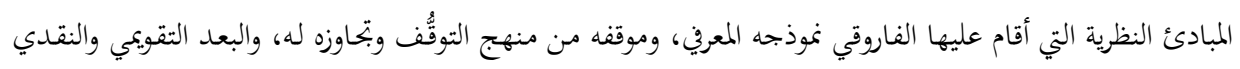
لذلك النموذج. الكلمات المفتاحية: إسماعيل الفاروقي، النموذج المعرفي، منهج التوقُف، ما وراء الدين، النمط المثالي، الفهم الديني.

\section{Abstract \\ The Epistemological Model of Al-Faruqi's Critique of Religions}

This paper discusses the methodological foundations stipulated by Ismail al-Faruqi to establish his epistemological model; where he put forth two main conditions: first, to engage in religious phenomenon and discover its logic; and second, to set principles for understanding religion and correcting that understanding, which is related to the theoretical principles which he considered as the foundation and means of acquiring and evaluation of knowledge. The paper addresses the theoretical principles upon which al-Faruqi based his epistemological model, and his position on the method of "Disengagement" (suspending) and the way he surpassed it. The paper also added the critique and evaluation dimension of the model.

Keywords: Ismail al-Faruqi, Epistemological Model, Disengagement Approach, Meta-Religion, the Ideal Trend, Religious Understanding.

" حاصل على الدراسات المعمقة من كلية الآداب جامعة محمد الخامس بالرباط، باحث في المركز المغربي للدراسات والأبحاث المعاصرة، باحث في مركز نماء للدراسات والبحوث. البريد الإلكتروني: talidi22@yahoo.fr

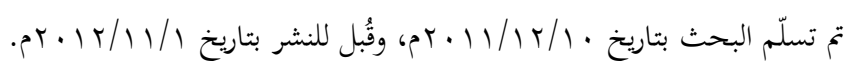




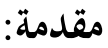

لم تنـل شخصسية إسماعيـل الفـاروقي حظهـا الكـافي مـن البحـث والدراسـة لا سيّما كتاباته ذات الطابع الأكاديمي، ' وبشكل أخص ضمن تخصصه في حقل نقد الأديان. ويرجع ذلك إلى جملة من الأسباب، من أهمها:

- التعقيد الذي تتسم به الظاهرة الدينية من جهة، والدراسات التي تتناولها. ويزيد هـذا التعقيد درجـة، كلمـا انتقلت الدراسـة مـن الوصف إلى التحليل، ثم النقــ والتجـاوز. وهذا ما يجعل الفئة المهتمة والمنشغلة بفكر الفاروقي في دراسة ونقد الأديان لا تتعدى ثلة من المتخصصين لا يغادرون دوائر البحث العلمي الجامعي. - - إن معظم ما كتبه الفـاروقي في دراسة الأديان ونقدها مكتوب باللغة الإبحليزية،

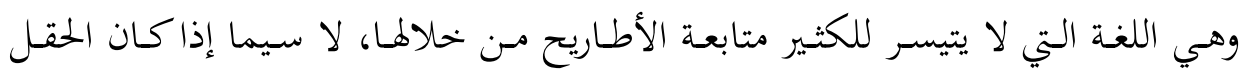

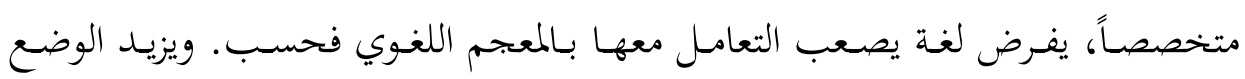

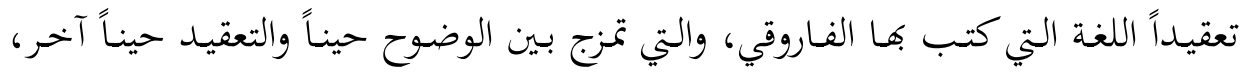
وأحياناً توليد المصطلحات الخاصة.

- الموقـف الـذي كـان يتخـــ في العـادة مـن الدراسـات الاجتماعيـة في عمومهـا، ودراسة الأديان على الخصوص؛ إذ لم يقع الانفتاح في العالم العربي والإسلامي على هذه الأدبيـات إلا مـع العقـود الثلاثنة الأخـيرة مـن القـرن الماضي، بـل لا تزال إلى اليوم تعـاني ج حظيت إسهاماته في دراسة الأديان بدراسات غربية كثيرة، نذكر منها إسماعيل الفاروقي وحوار الأديان: الإنسان

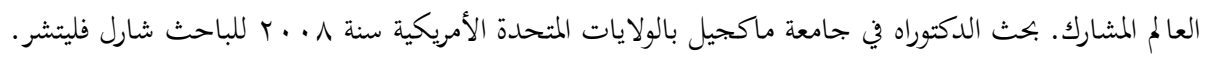

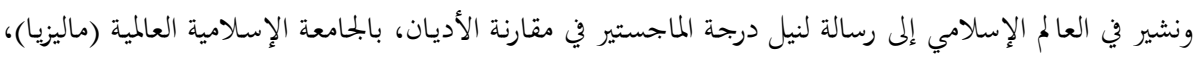

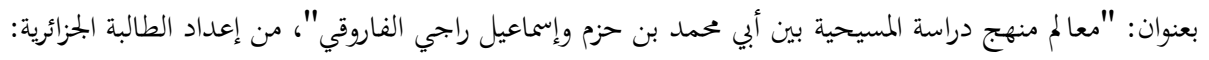

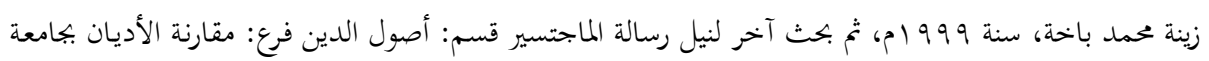

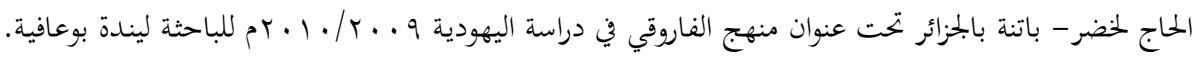

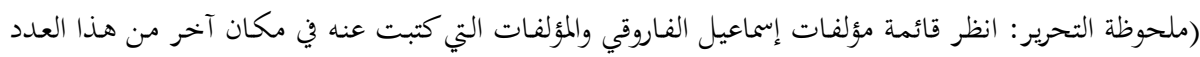


عقبات في سبيل تمهيد الطريق أمام خلاصاتا، لا سيّما في بحال الدراسات الأنثروبولوجية ودراسة الأديان.

ولـئن كانـت بعض الأطروحـات البحثيـة حاولـت أن تقـترب مـن أطروحـة الـدكتور إسماعيل راجي الفاروقي لدراسة ونقد الأديان، إلا أهـا -على الجههد الكبير الذي قامت

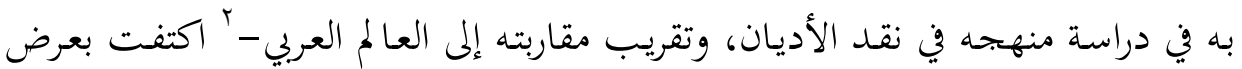

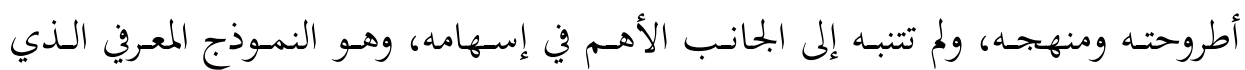
أسّس له الفاروقي في دراسته للأديان.

وتأتي هذه المساهمة لتكمل هذه الجهود، وتضيف إليها البعد الغائب عنها، وتكشف

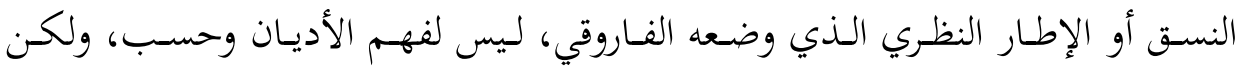

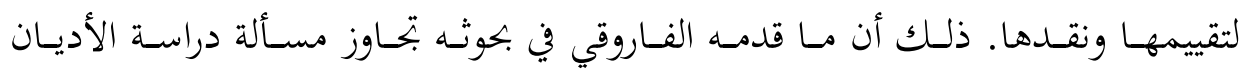

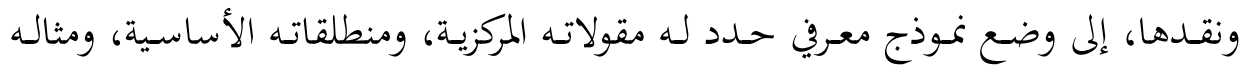

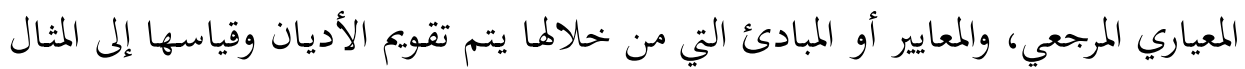

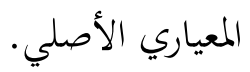

وقـد بسطت مقدمـة كتابـه -"الأخهالاق المسـيحية"- كل هـذه الجوانب، وكشـفت بوضوح عن منهجية الفاروقي والنموذج المعري الذي يتبناه. ولذذا السبب، سنجعل هذه

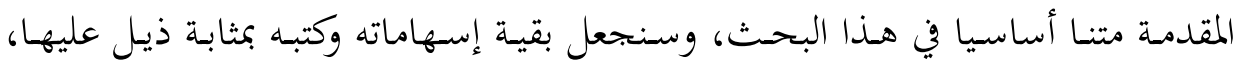
يوضح غامضها، ويفصل بحملها، ويمثل لها، ويقرر ويؤكد اختياراتا المنهجية.

على أن جعل مقدمة هذا الكتاب المتن الأساسي لهذا البحث، لا يعني بالضرورة أن

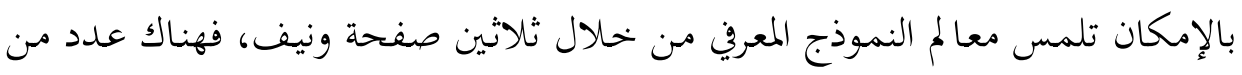
الأفكار والانتقادات التي آخذذ بها الفـاروقي جهود مـن سبقه في دراسة الظاهرة الدينية، ' بسبب إسهامات الفاروقي في نقد الأديان ومقارنتها، وكتابتها باللغة الإنخليزية، وبسبب التعقيد الذي يطبع لغته

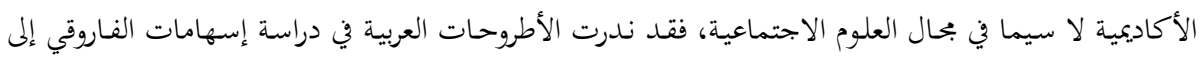

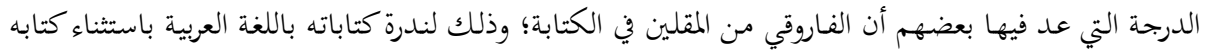

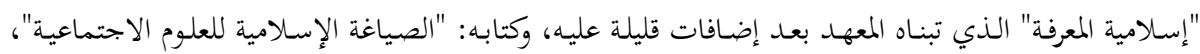

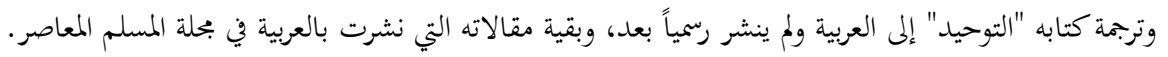


كما أن هناك عدداً من المقتضيات المنهجية التي كوّنت لدى الفاروقي قناعات راسخة

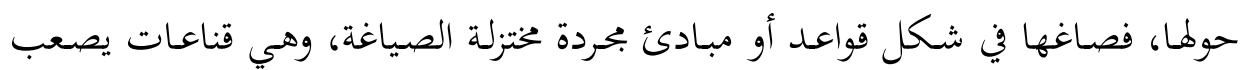

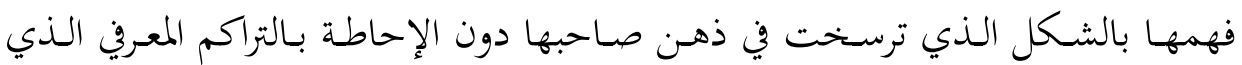
حقّقه الفاروقي؛ إذ كيف يمكن فهم المبادئ النظرية التي صاغها للفهم الديني دون معرفة

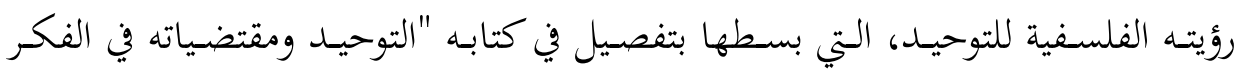
والحيـاة"، وكيـف يمكـن فهم تعقبـه المنهجي للبـاحثين الغربيين في حقـل دراسـة الظـاهرة الدينية دون معرفة رؤيته للعلوم الاجتماعية ومنهج دراستها!

أوّلاً: في المصطلح والمنهج:

\section{I ـ تحرير المصطلحات والمفاهيم:}

قبـل تلمّسس معـالم هـذا النموذج، يجـدر بنـا أن نضع بـين يـدي مقدمـة هـذا البحـث

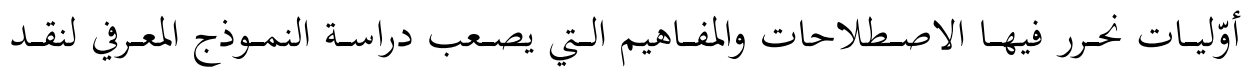

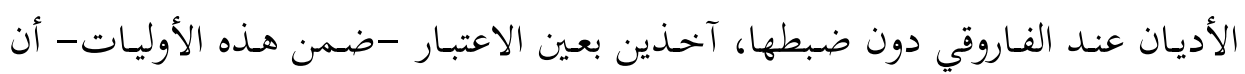
علم الأديان ودراسته المقارنة مما لا يحتاج إلى تعريف، ما دام الفاروقي في نموذجهـ المعرفي

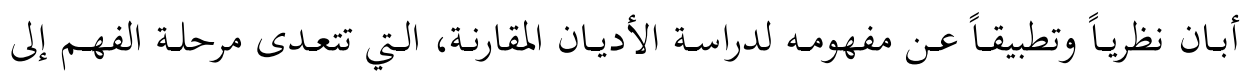

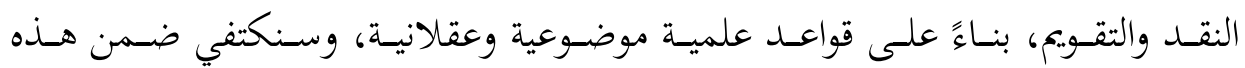
الأوّليات بتوضيح دلالات الاصطلاحات الآتية عنده:

أ. مـا وراء الأديـان: "Metareligion" لم يهــد الفـاروقي هـذا المفهـوم مـن بنائهـ الاشـتقاقي المركب مـن كلمتـين: "ميتـا"و "ديـن" ولعـل ذلك راجـع إلى أن اللغـة الانجليزيـة

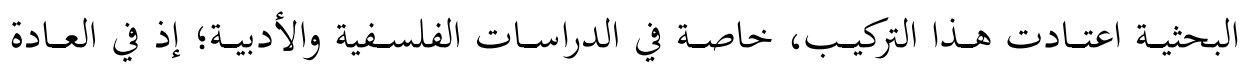

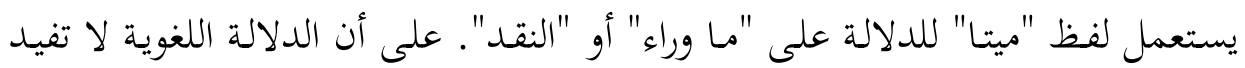
كثيراً بالقياس إلى الدلالة العلمية للمصطلح، الذي نحته الفاروقي نحتاً خاصاً وضمّنه جملة

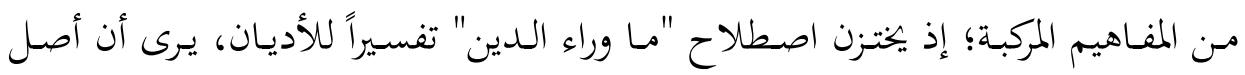

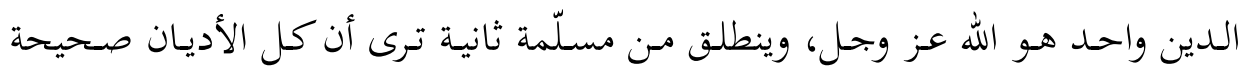


النسبة إلى مصدرها ما لم يثبت تاريخياً أنه قد لابسها إضافة بشرية أو أها في الأصل من

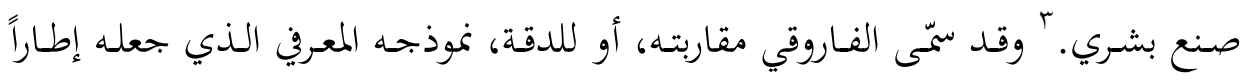

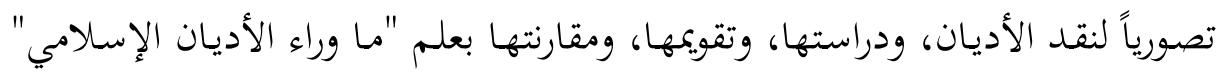
|Islamic meta-religion

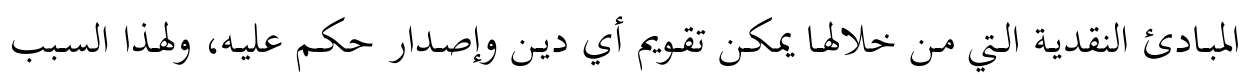

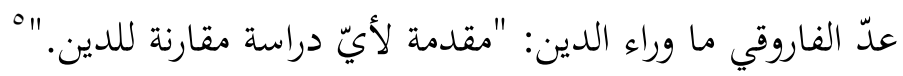

ب. النمـوذج المعـري: لم يستعمل الفـاروقي في دراسـاته وبكوثـه حـول الأديـان هـذا

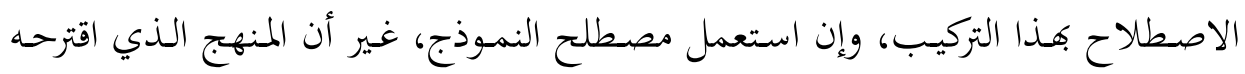
والتزمه في دراسة الأديان يصدق على المواصفات التي تكون في العادة في النموذج المعرين.

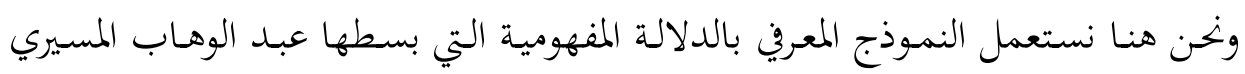

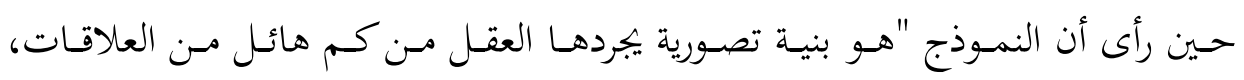

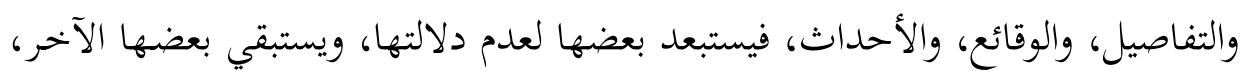

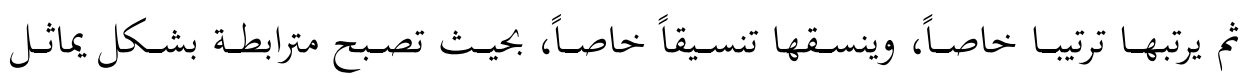

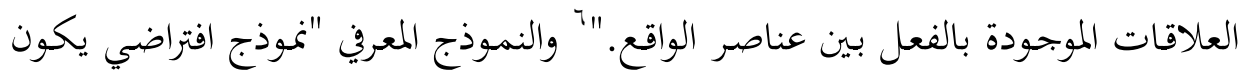

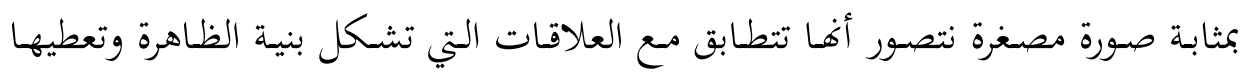

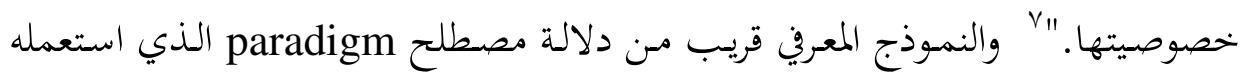

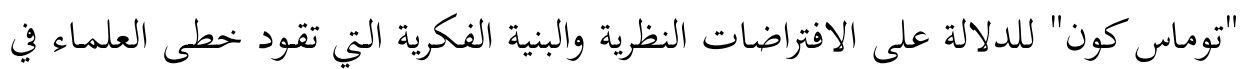

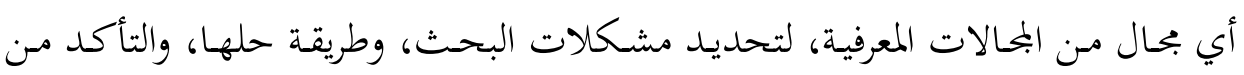
صحة الحل." "^ وهذه الافتراضات النظرية هي مجموعة من المعتقدات الأساسية التي تقود

${ }^{3}$ Ismail Al-faruqi, Towards an Islamic theory of meta-religion: www.ismailfaruqi.com.

(16-12-2009) http://www.ismailfaruqi.com/articles/towards-an-islamic-theory-of-metareligion/

${ }_{5}^{4}$ Ibid.

${ }^{5}$ Al-Faruqi, Christian Ethics: A Systematic and Historical Analysis of Its Dominant Ideas. (Montreal: McGill University Press, 1967), p21.

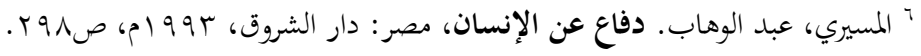

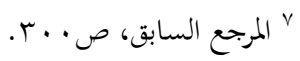

8 Kuhn, Thomas. The Structure of Scientific Revolutions, Chicago: University of Chicago Press, 2nd edition, with postscript. 1970,.p.38-39 


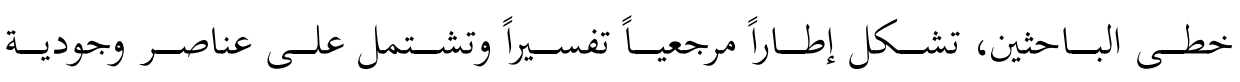

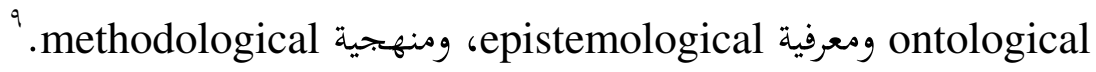

ت. ت الـنمط المثـالي: وهـو المـنهج الـذي تبنـاه (مـاكس فيـبر) بوصـفه أداة تحليليـة في دراساته الاجتماعية، كَدف إلى عزل بعض جوانب الواقع وإبرازها، حتى يتسنى إدراكها بوضوح ومعرفة أثرهـا على الأرض، والنمط المثالي كما استقر عند (فيبر) لا يفترق كثيراً عن النمـوذج المعروي، فكالاهما نموذج افتراضي، يُقصدـ مـن خحلاله تسـهيل دراسـة الوقائع والظواهر الاجتماعية، والقدرة على تفسيرها.

\section{Y. ما قبل النموذج المعرفي أو الحاجة إلى نقد مناهج دراسة مقارنة الأديان:}

لا يمكن أن ننفي التأثير الكبير للمنهج الظاهراتي - الفينومينولوجي - على دراسات الفـاروقي في نقـده للأديـان، غـير أنـه ألمـح مبكـراً إلى صعوبة فرض المعـايير المنهجيـة التي اكتسبها الباحثث من تخصصه المعري على الظاهرة الدينية، كما نبّه على أعطاب المنهج الذي يسعى إلى تطبيق معايير اكتسبها الباحث من دراسته لدينه أو ثقافته على دين آخر أو ثقافة أخرى. وانطلق في تقويمه لمسألة المنهج المقارب لدراسة الأديان، من التأكيد على ضـرورة إعـادة النظـر في كيفيـة النظـر إلى الظـاهرة الدينيـة بوصـفها ذات طبيعـة مركبـة، فالظـاهرة الدينيـة -بتعبير الفـاروقي - هي حقيقـة الحيـاة life Fact، بجمـع بـين الحقـائق البحردة والقيم المعيارية في نظام تركيبي معقد، يصعب معه التزام معايير دين معين أو ثقافة معينة، وفرضها على ديـ آخر أو ثقافة أخرى. وبنـاء على هذا المنطلق المنهجي الذي ينطلق مـن تحديد طبيعة الظاهرة الدينية المركبة، فقد ألح الفـاروقي على مطلبين منهجيـين أساسيين:

أ. مطلب فلك الارتباط: يرى الفاروقي أنه لا بدّ على الباحث أن يضع معاييره أو معايير دينه أو ثقافته بعيداً، وأن ينخرط من داخل الظاهرة الدينية، ويكتشف منطقها من الـداخل، فمطلـب فـك الارتبـاط بـالأطر المرجعيـة والمنهجيـة للباحسث تعينـه على رفـع

9 Denzin, N. K. \& Lincoln, Y. S. (Eds.), Handbook of Qualitative Research (2nd ed.), Thousand Oaks, CA: Sage Publications, Inc. 2000, p. 19. 
المشوشات والعقبات التي تمنعه من فهم الظاهرة الدينية، واكتشاف منطقها الداخلي. '1

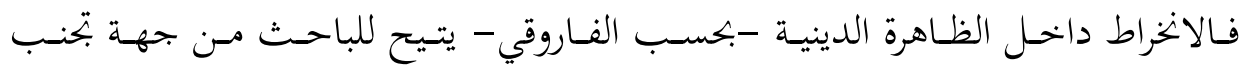

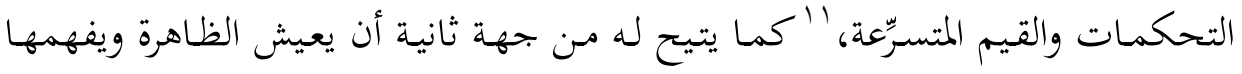
كمـا هـي في حقيقتهـا، ليتسـنى لـه الانتقــال بعـــ ذلـك مـن عمليــة الفهـم إلى التقـويم الموضوعي لما.

وهكذا، فمن أجل فهم حقائق الحياة التي تقدمها الظاهرة الدينية، يجب تطبيق مبدأ التوقف وفـك الارتبـاط. إفها -بحسبب الفـاروقي - طريقـة لتجنـب مزالق المنهج الواقعي، والمنهجـي المثالي على حسد سـواء، والتحـرر مـن الافترضـات والقـيم مـن أجسل أن يخطو الباحث إلى هذه الأديان التي يريد أن يدرسها. ولاكتساب معرفة بحقائق الحياة لدين من الأديـان، ينبغي للباحـث أن يسمح لفهمـه أن يلمسس حقيقـة الـدين المـدروس وأن يـترك للـدين أن يخبره عن حقيقته كمـا هي، وذلك عن طريق التجربـة والانخراط مـن داخلل الظاهرة الدينية. فيؤكد الفـاروقي بـلك على خهوض التجربـة التي تتضـمن التعـاطف مـع

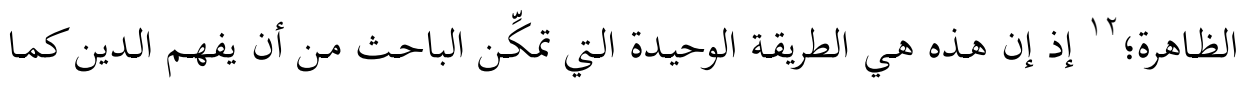
يفهمه المعتنقون له، وأن يسمح للدين أن يتكلم كما هو .

${ }^{10}$ Rashid, Zuriati bt Mohd and Alwi, Engku Ahmad Zaki Engku. "Al-Faruqi and His Views on Comparative Religion: "International Journal of Business and Social Science Vol. 1 No. 1, October 2010 " يقول الفاروقي في مساهمته: "فالملاحظ لا يستطيع أن يقيم القوانين التي تحكم الواقع الاجتماعي إلا إذا اتبع بشكل

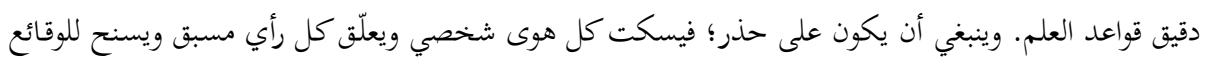

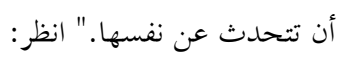
- الفاروقي، إسماعيل. العلوم الطبيعية والاجتماعية من وجهة النظر الإسلامية، ترجمة: عبد الحميد محمد الخريبي،

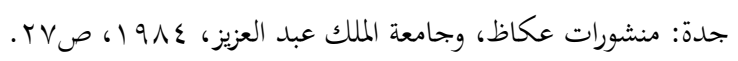

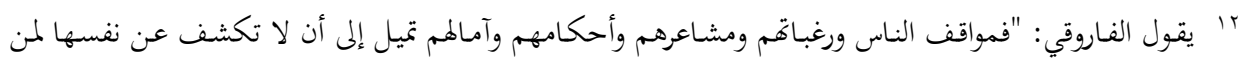
يلاحظها دون تعاطف معها." انظر:

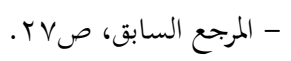


ب. الحاجة إلى وضع مبادئ لفهم الدين وتقويمه: فعملية فهم الدين كما مرّ بنـا لا

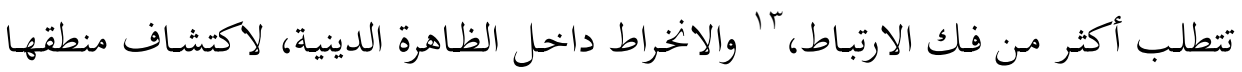

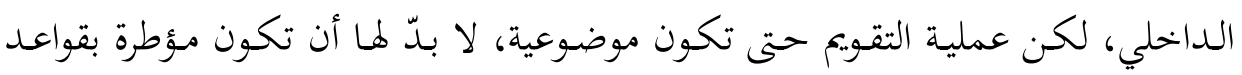

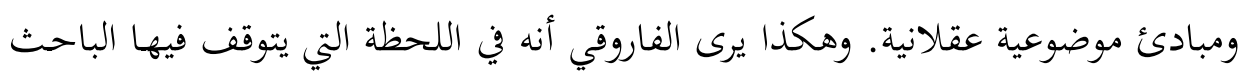

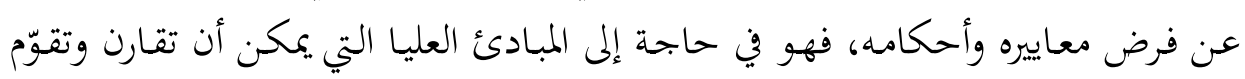

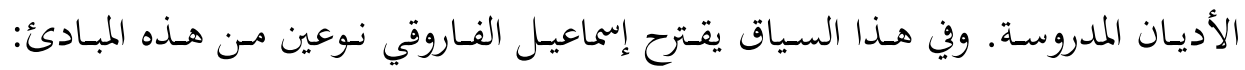

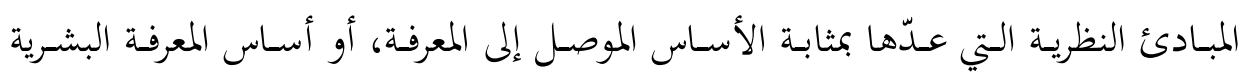
بشكل عام، ثم المبادئ التقويمية.

بيد أنه حرص على أن يجرد هذه المبادئ عن المصاحبات العقدية حتى يضمن عدم

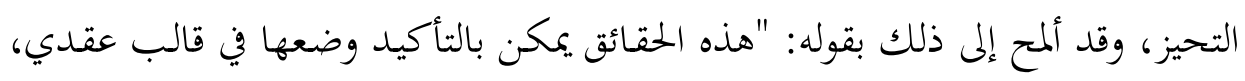

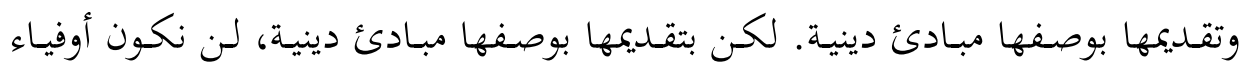
لقصدنا." أ وقد أراد بذلك أن يتجنب السقوط في ما انتقد عليه الباحثين الغربيين الذين

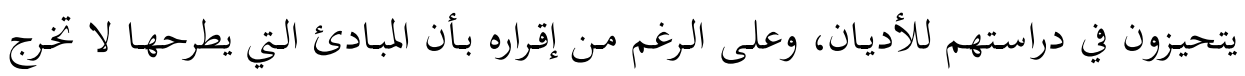

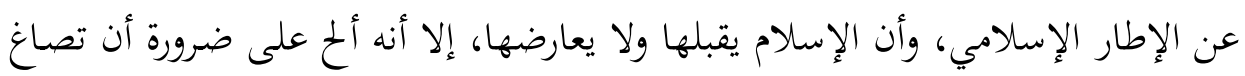
بشكل فلسفي، وليس بصيغ عقدية ودينية حتى تكون حقائق عقلانية ونقدية. 10

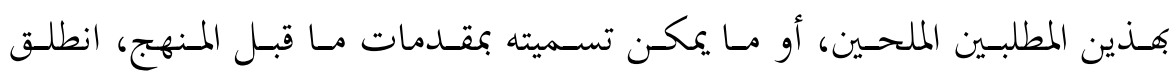
الفاروقي في دراسة الأديان ومقارنتها جامعاً في ذلك بين ثلاثة أبعاد منهجية:

- البعد الوصفي: وهو الذي استعمله عند عرض الدين وتقديم الحيثيات والعناصر

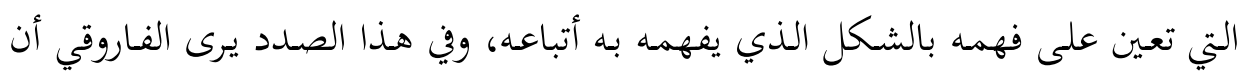

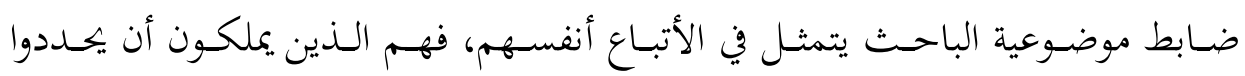
موضوعية الباحث ومصداقية خلاصاته.

${ }^{13}$ Rashid, Zuriati bt Mohd and Alwi, Engku Ahmad Zaki Engku. "Al-Faruqi and His Views on Comparative Religion".

${ }^{14}$ Al-Faruqi. Christian Ethics, $p 31$.

15 " We hold those truths to be the self-evident element of a philosophy that is critical, by any standard or sense of the term. These are rational, not dogmatic truths. They are open to question, to be sure; but whosoever wishes to content them cannot do so from the standpoint of dogma." Ibid, p31-32. 
- البعد المقارن: حاول الفاروقي أن يدرس القواسم المشتركة، ونقاط الاختلاف بين

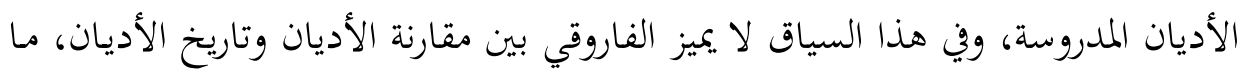
دام كل واحد منهما يعرض لقضايا الأديان، ويشرحها، ويؤرخ لها ويقارن بينها. - البعد النقدي أو التقويمي: وهـو يأخـذ موقعاً مركزيـاً في مقاربـة الفـاروقي، ويعزو الفـاروقي الحاجـة الملحـة إلى النقـــ إلى طبيعـة المـادة المدروسـة، بمـا هي الظـاهرة الدينيـة في تركيبها وتعقـدها، وفي هـذا السـياق يـرى الفـاروقي -كمــا رأينـا- أنـه لا بـدّ مـن قواعـد ومبادئ موضوعية وعقلانية تسعف في النقد والتقويم، وأن هذه المبادئ ينبغي أن تكون معلنة غير مضمرة ولا مخفية حتى يكون النقد واضح المعالم، ومبنياً على أسس موضوعية وعقلانية.

وسنحاول في هذا البحث أن نتناول النموذج المعري لنقد الأديان عند الفاروقي من خهال خمسـة محاور هي: المقولات التأسيسية التي أقام عليها الفـاروقي نموذجـه المعرفي،

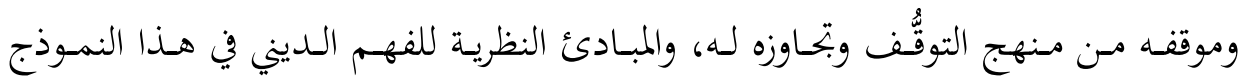

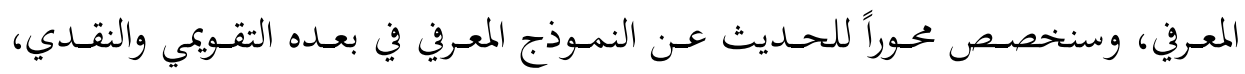
وضمنه سنتناول المبادئ التقويمية التي وضعها الفـاروقي لنقد الأديان وتقويمها، وسنتختم الدراسـة بالبحـث عـن الصـلة والعلاقة بـين النمـوذج المعروي لنقـد الأديـان عنــ الفـاروقي، والنمط المثالي في دراسة الظواهر ومنها الظاهرة الدينية.

\section{ثانياً: المقولات التأسيسية للنموذج المعرفي لنقد الأديان عند الفاروقي}

أسّس الفاروقي لنموذجه المعرفي من منطلق منظوره الفلسفي للتوحيد، ولرؤيته للعالم، ولطبيعة دور الإنسـان في هذا الكون؛ أي باستحضـار نظام العلائق التي تربط العناصر الثلاثـة: الله، والكـون، والإنسـان. وهـو، وإن بتحـب صـياغة مقاربتـهـ بلغـة دينيـة، إلا أن فلسفة التوحيـد تبقى حاضـرة بقـوة، ليس فقـط على مستوى المقـولات التي بـنى عليها ${ }^{16}$ Ibid, p21. 
نموذجه المعرفي "ما وراء الدين"، ولكن أيضاً على مستوى المبادئ النظرية والتقويمية التي وضعها -أو بالأحرى التي استلهمها من فلسفة التوحيد- لنقد الأديان وتقويمها.

ومسن خهالال تتبُّع كتابـات الفـاروقي، لا سيّما كتابـه "الأخهاق المسيحية" أو بحثه. الموسـوم بـ"مـن أجـل نظريـة إسـلامية لما وراء الـدين" يمكـن أن نسـتقرئ ثـلاث مقـولات مترابطة، ومتدرجة، حاول الفاروقي أن يبني عليها نموذجه المعرفي: 1 ـ المقولة التأسيسية الأولى: "إن الأديان كلها من أصل واحـد." ا' وينطلق في ذلك مـن حقيقـة مفادها أنه مـا مـن قوم إلا وأرسـل الله إليهم رسـالً ليبلغوا الدين الذي

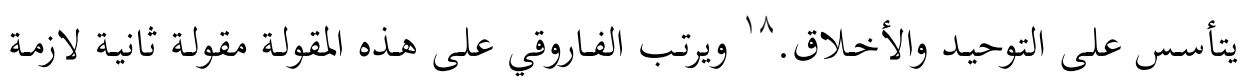
للمقولة الأولى، وهي:

لايستعين الدكتور الفـاروقي بالتمييز داخل الوحي بين مفهوم الماهية ومفهوم الكيفية، لتفسير اختلاف الأديان في

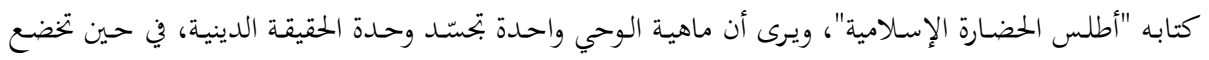
كيفية التنزيل لجملة من المسوّغات. يقول: "وقد فرق التنزيل الإسلامي بين "الماهية" و "الكيفية" وأصبح الأمر الثاني

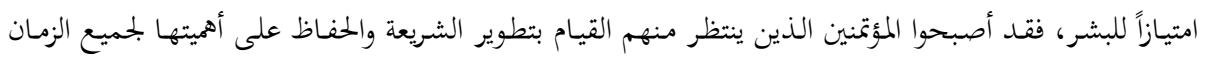
والأماكن بملاءمتها مع ما تفرضه ظروف البمتمعات المتغيرة. ولكن إذا أريد لهذا الجههد من جانب البشر ألا يؤدي

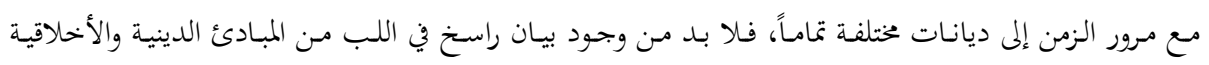
يستطيع كل إنسان أن يعود إليه بوصفه الأساس الأخير للتشريع بأسره. انظر: - الفاروقي، إسماعيل راجي، لوس لمياء الفاروقي. أطلس الحضارة الإسلامية، ترجمة وتحقيق: عبد الواحد لؤلؤة،

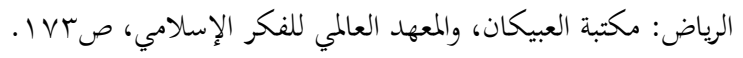

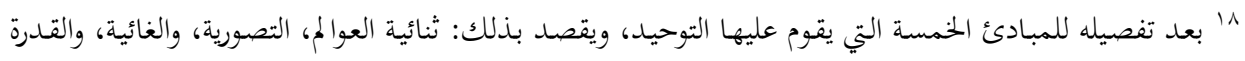

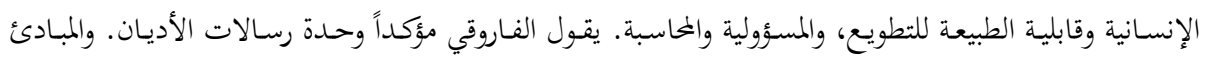

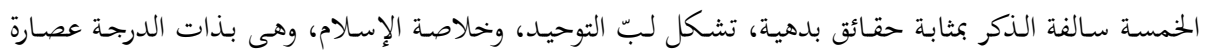

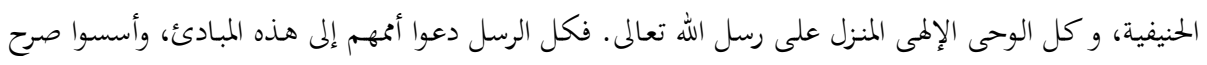
رسالتهم عليها. وبالمثل، فطر الله تعالى البشرية على هذه المبادئ، فهى مركوزة في نسيج الطبع الإنسانى، وتمثل فطرة

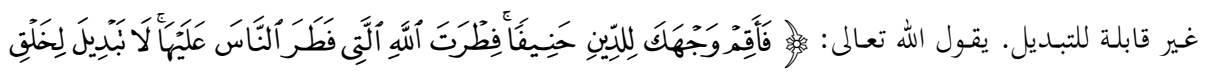

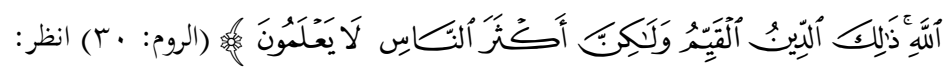
- الفاروقي، إسماعيل راجي. التوحيد ومضامينه في الفكر والحياة، ترجمة: سيد عمر، نسخة إلكترونية، ص به له 
Y. المقولة التأسيسية الثانية: "كل دين يفترض أنه دين صحيح ينتسب إلى الدين

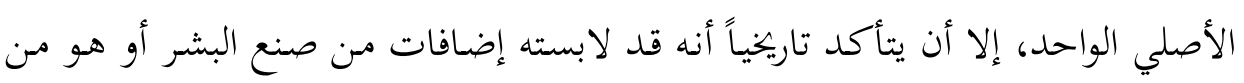

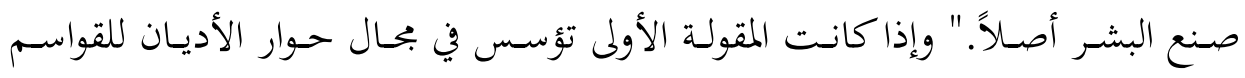

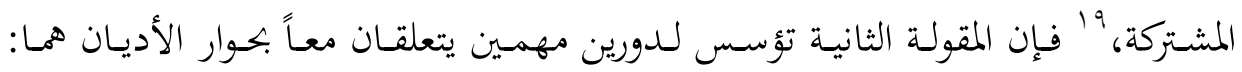

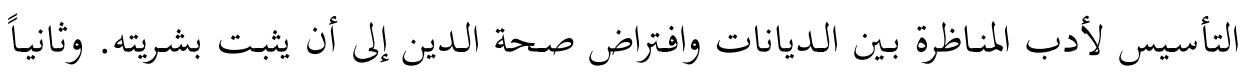

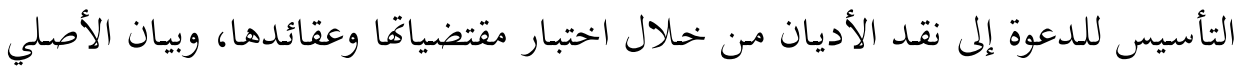
فيها، وما كان من إضافات الصنع البشري. ويترتب على هاتين المقولتين مقولة ثالثة، هي:

r. المقولة التأسيسية الثالثة: رفض إدانة أو اتحام أي دين، مـا دام مـ الضروري

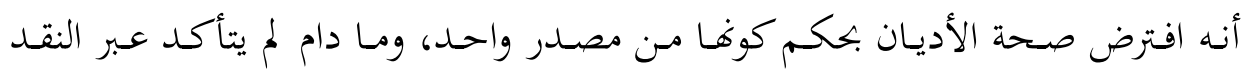

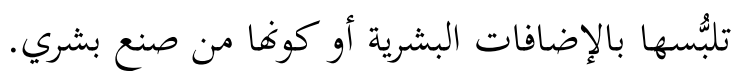

ع ـ المقولة التأسيسية الرابعة: وهي المكانة التي تبوأهـا مقاربته للعقل؛ إذ بتعله

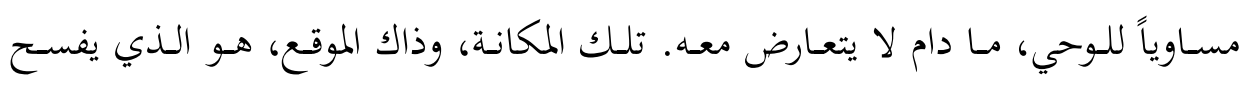

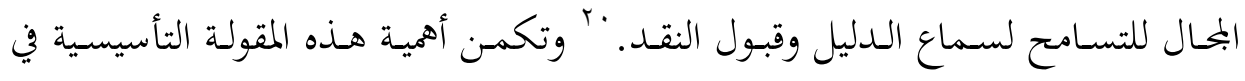

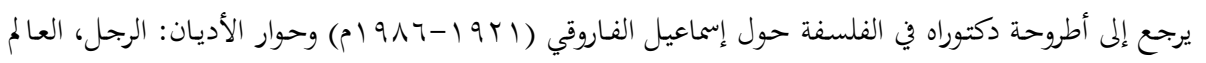

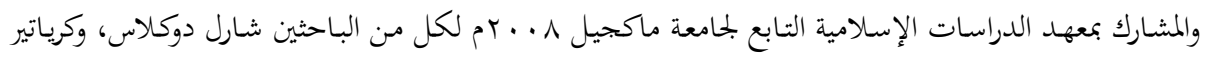

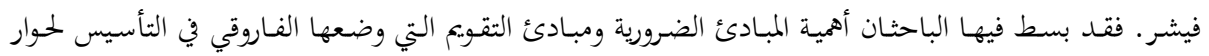

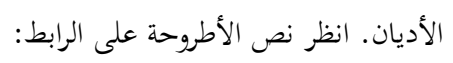

http://digitool.library.mcgill.ca/view/action/singleViewer.do?dvs=1379452350613 477

\&locale=fr_FR\&show_metadata=false\&VIEWER_URL=/view/action/singleViewer.

do?\&DELIVERY_RULE_ID=6\&adjacency=N\&application=DIGITOOL-

$3 \&$ frameId $=1 \&$ usePid $1=$ true \&usePid2=true

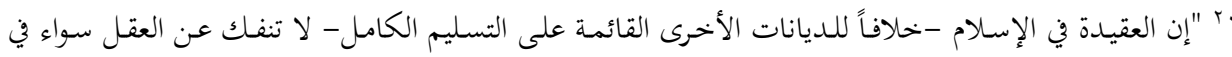

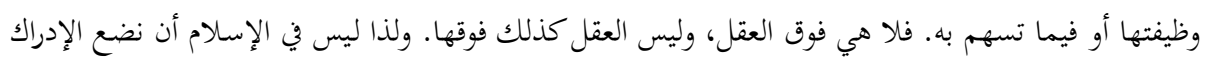

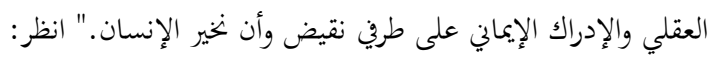

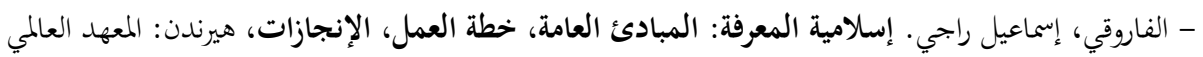

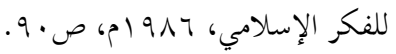




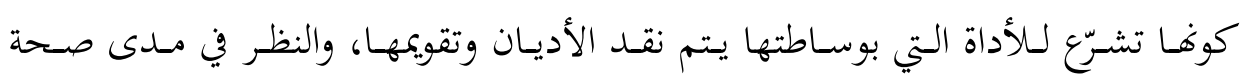
انتسابها إلى الدين الأصلي أم انزياحها عنه بسبب الإضافات البشرية التي صاحبت تطوره التاريخي.

\section{ثالثاً: النموذج المعرفي لنقد الأديان عند الفاروقي: من التوقُّف إلى الفهم:} كان الدكتور إسماعيل الفـاروقي واعياً بأنه يصعب دراسة الظاهرة الدينية بالمنهج

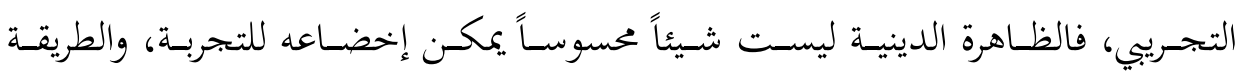

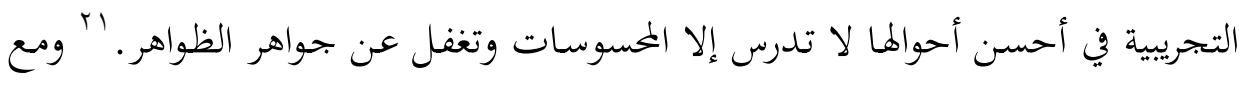

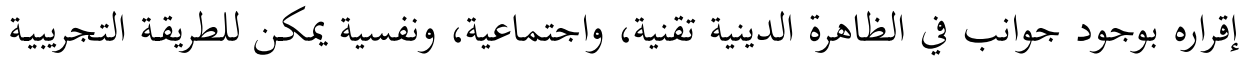

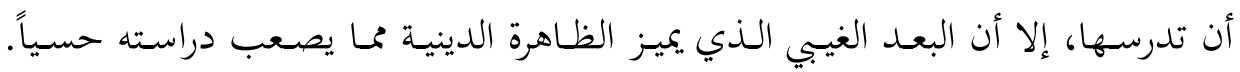

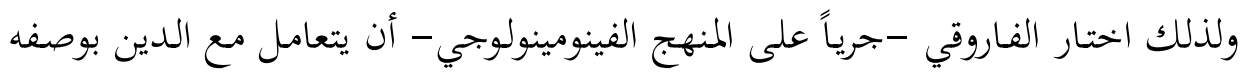

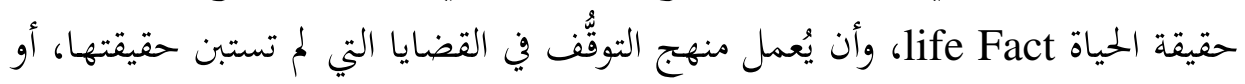

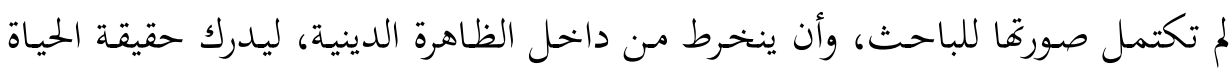

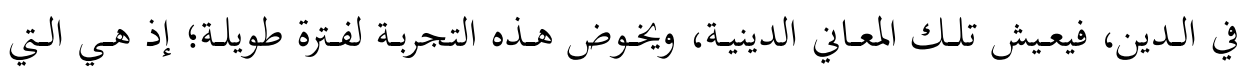

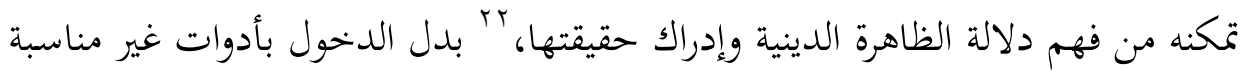

\section{${ }^{21}$ Christian Ethics, p3.}

يقول الفاروقي موضحاً ذلك: "لم يكن المنشغل بالطبيعة الإنسانية والبحتمع من الغربيين مستعداً للتحقق

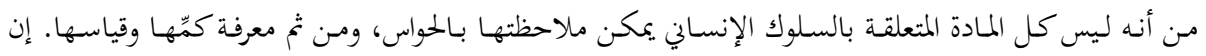
الظاهرة الإنسانية لا تتكون من عناصر مادية خالصة، فالعناصر ذات النمط المخالف، نمط المعنويات والروحانيات

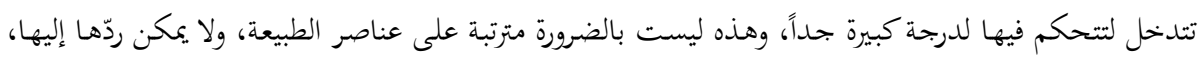

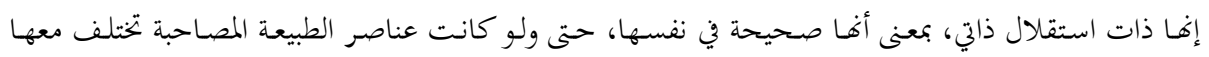

$$
\text { وتطغى عليها." انظر: }
$$

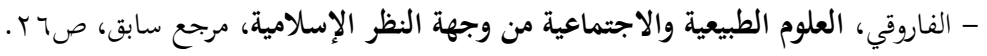

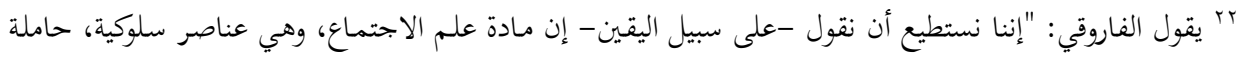

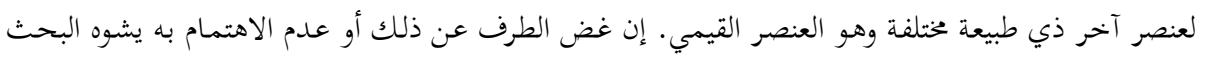

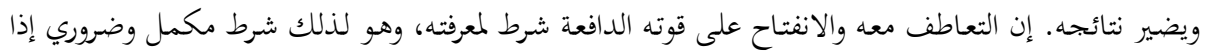


لدراسة موضوع فيه من التعقيد، والتركيب، والتداخل بين الغيبي والحسي ما يصعب معه إدراك حقيقته.

لكن منهج التوقُّف هـذا، لا يعني عند الفـاروقي فاية الطريق بالنسبة إلى الحقائق المستعصية على الفهم في الظاهرة الدينية، وإنما هو خطوة مؤقتة فحسب، لا بدّ أن تتلوها

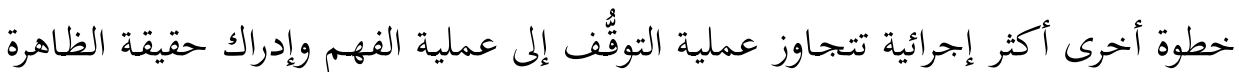
الدينية. ولهذا، رغم اعتراف الفاروقي في أطروحته "الأخلاق المسيحية" بأهمية ما تمثله هذه

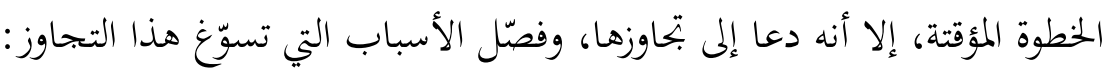

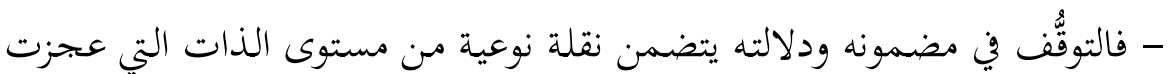

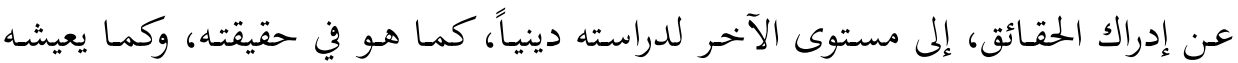
أتباعه.

- والتوقف يمثل -بحسب الفـاروقي - تقدماً نوعياً في الدراسـات المقارنة للأديـان،

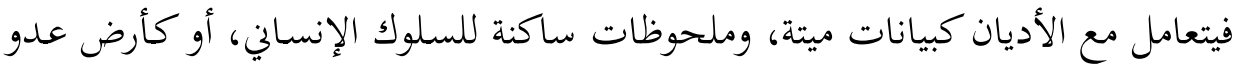

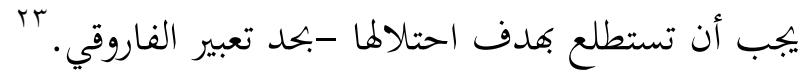

- ومن منطلق رؤيته بأن الظاهرة الدينية هي حقيقة حياة، يرى الفاروقي أن منهج

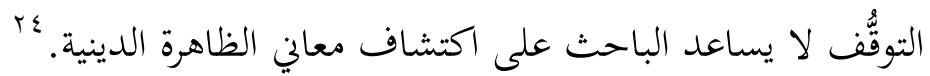
ولهذه الأسباب، ترتّب عن نقد الفاروقي لمنهج التوقف، طرح منهج آخر أحدث

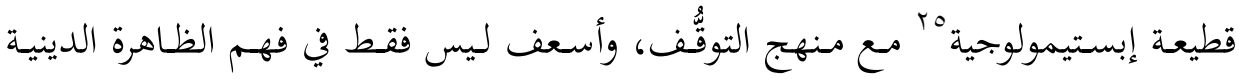
بشكل كامل في أبعادها الغيبية والحسية، ولكن أيضاً في نقدها وتقويمها.

كـان للنتائج أن تكـون مطابقـة للواقع، وإن مواقف الأفراد والجماعـات ومشـاعرهم وآمـالهم لا تتحـدث إلا إلى

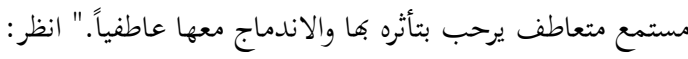

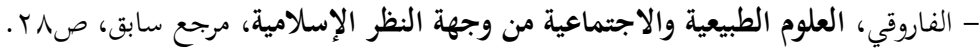
${ }^{23}$ Christian Ethics, p8-9.

${ }^{24}$ Ibid., p9. ro نستعمل هنا مصطلح القطيعة الإبستمولوجية بتحديد غاستون باشلار، والذي يعني الجمع بين الاحتواء والتجاوز. 
وضمن أطر المنهج الجديد الذي اقترحه الفاروقي، تم وضع أربعة مبادئ عدّها بمثابة

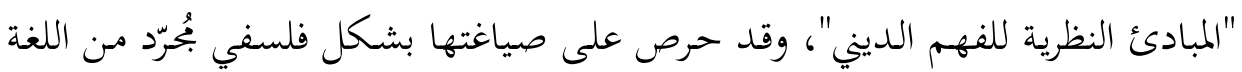

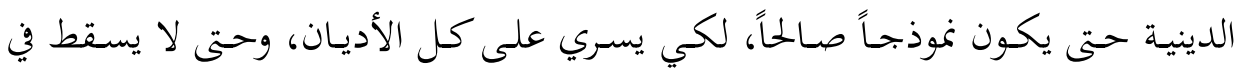
التحيّز . وقد وضع الفاروقي هذه المبادئ انسجاماً مع الأطر المنهجية الآتية: ا ـ الانسجام مـع الؤيسة المنهجية الكلية في دراسـة الأديان، ذلك أنه اشترط

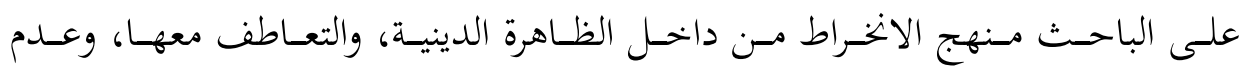

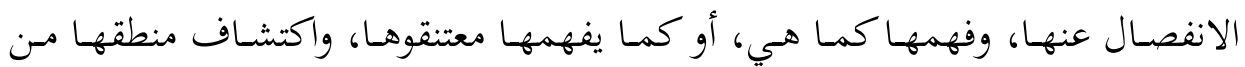

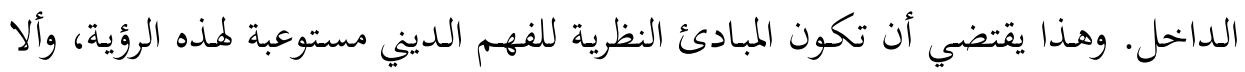

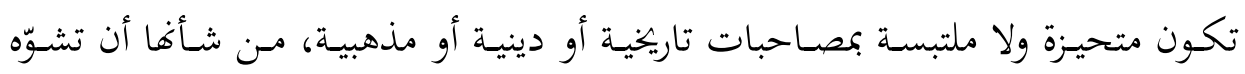
صورة الظاهرة الدينية، وتحرّفها عن حقيقتها. ץ. الانسجام مع المقولات التأسيسية: ذلك أن المقولة الأساس التي تتفرع عنها

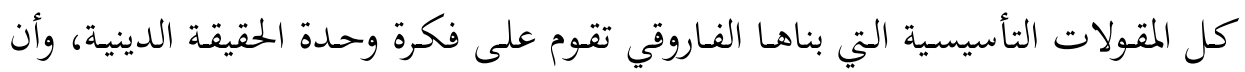

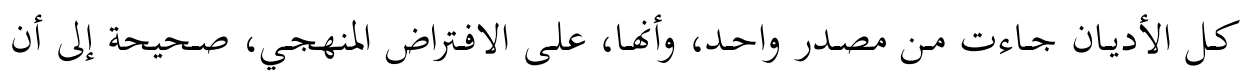

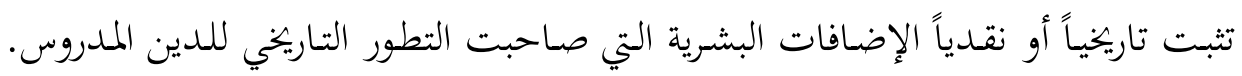

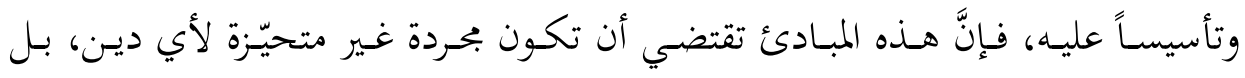

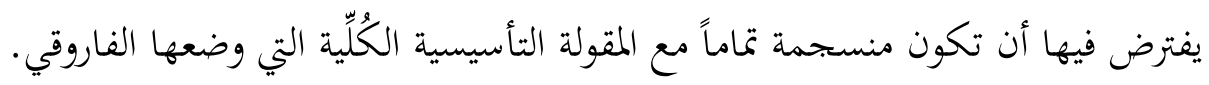
r. الضرورة التي يفرضها النموذج المعرفي: فمن شرط النموذج المعري أن يكون

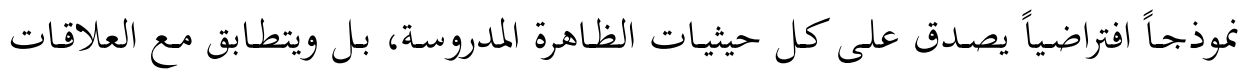

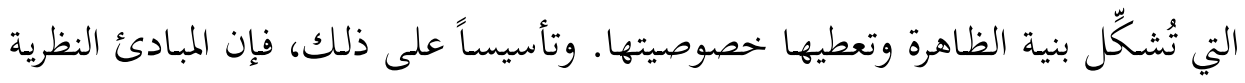

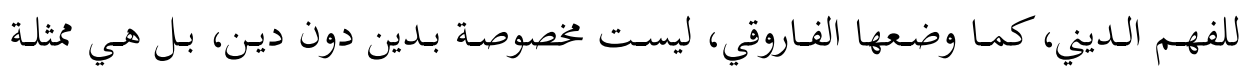

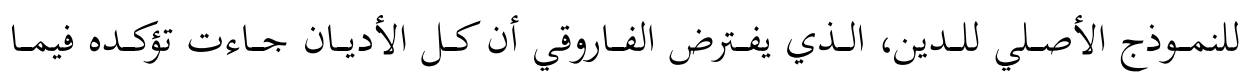
يسميه بوحدة الحقيقة الدينية. 
ع . إن هـذه المبـادئ جـاءت؛ لتتجـاوز التحـديات المعرفيـة التي فرضهها مـنهج

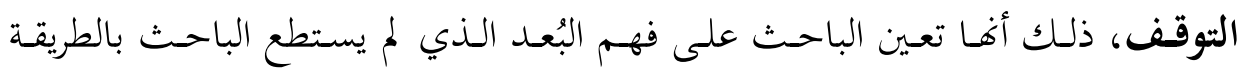
التجريبية أن يغطيه علمياً.

رابعاً: المبادئ النظرية للفهم الديني في النموذج المعرفي عند الفاروقي تأسيساً على الأُطر المنهجية السابقة التي اشترطها الفاروقي، وضع الفاروقي المبادئ

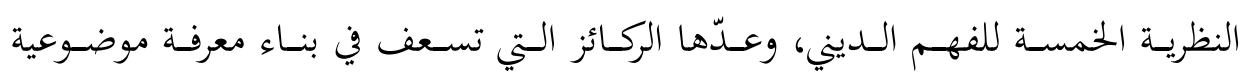
وعقلانية تستدرك الأعطاب المنهجية التي سقطت فيها مناهج البحث الغربي، التي تقوم

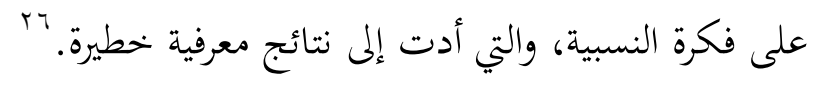

المبدأ الأول: الانسـام الداخلي: ويعني به أنّ أي نظام يفترض ألا تتعارض

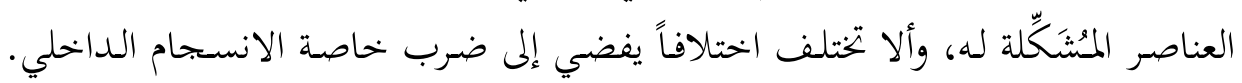

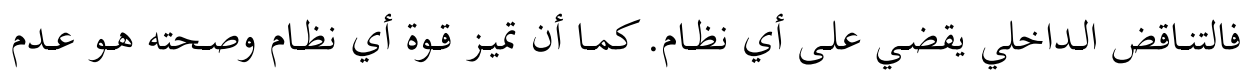
وجود هذا التناقض، أو هو الاتساق الداخلي بين جميع مكوناته وعناصره. وهـأ المبدأ

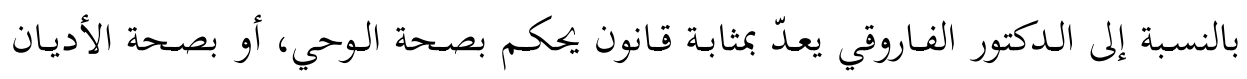
المنزلة.

• المبـدأ الثاني: الانسـجام مع المعرفـة الإنسـانية المتراكمـة: ومقتضـاه أن أي

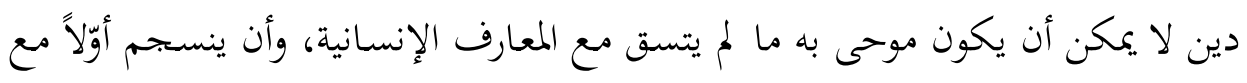

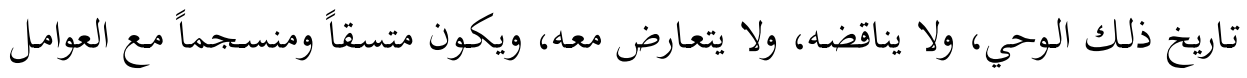

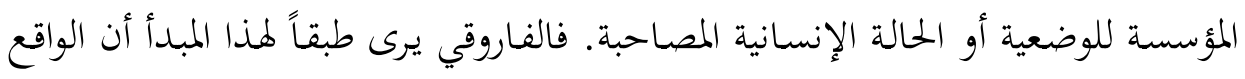

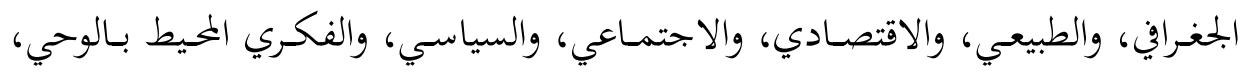
يشكِّل عوامل حاسمة في فهمنا للحقيقة الدينية الموحى بها.

المبـدأ الثالث: مبـدأ اتسـاق الحقيقة الدينيـة مع الخبـرة الدينيـة الإنسـانية:

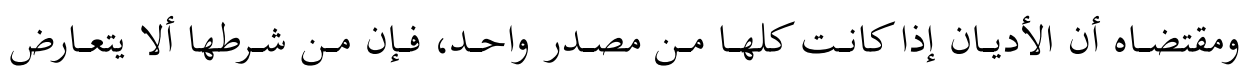

${ }^{26}$ Ibid., pp. 13-14. 


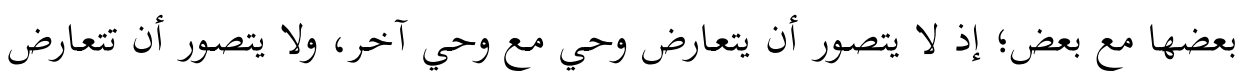

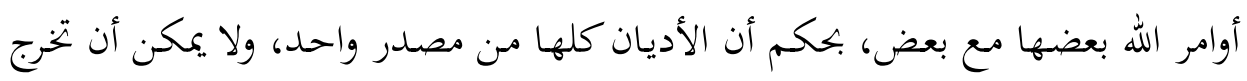
عن تمثيل وحدة الحقيقة الدينية.

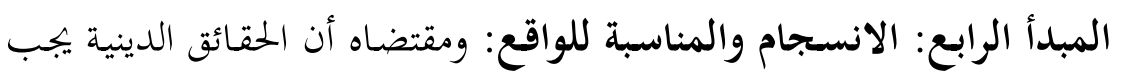

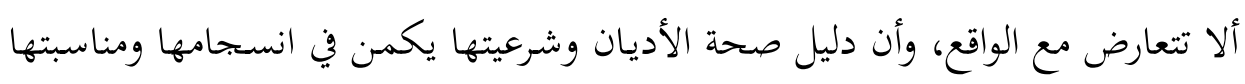

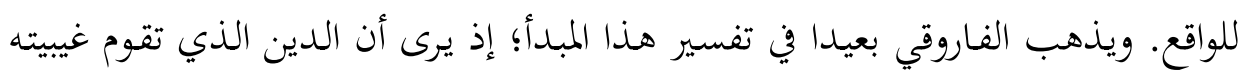

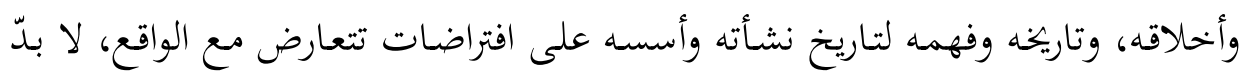

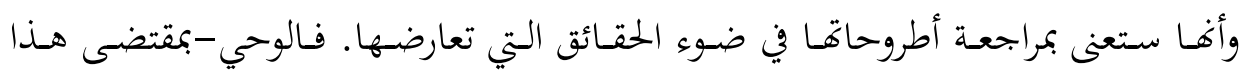

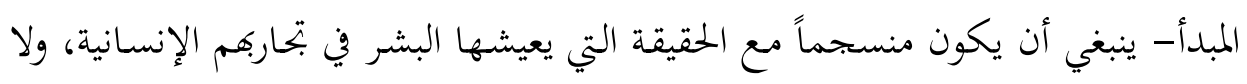

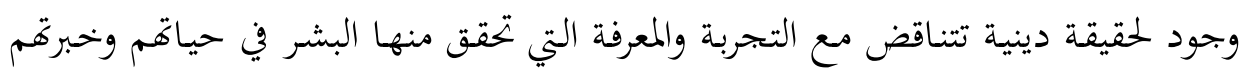
الواقعية.

المبـدأ الخهامس: مبـدأ الهـدف الحقى، أو خدمـة الـدين للأخسلاق والخيـر

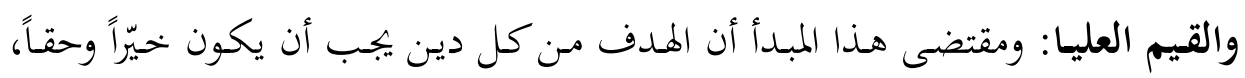

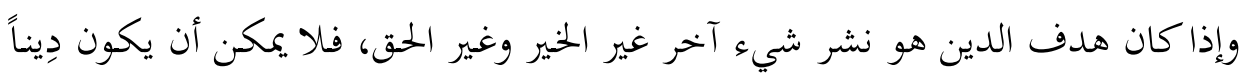

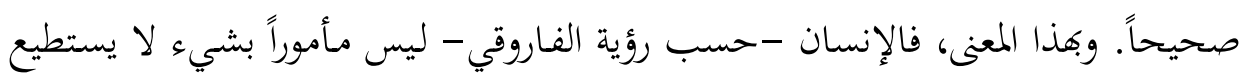

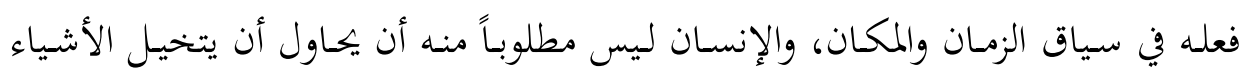

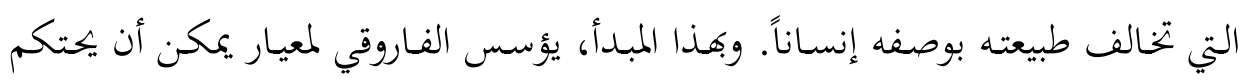

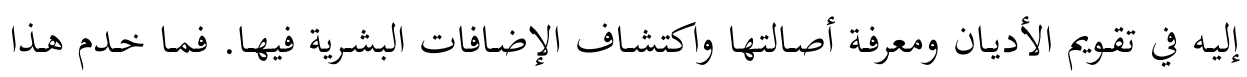

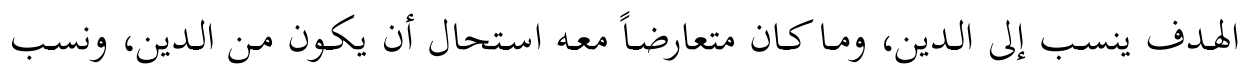
بالضرورة إلى الإضافات البشرية.

والناظر في هذه المبادئ النظرية المحردة الخالية من اللغة الدينية في الصياغة، لا يجد

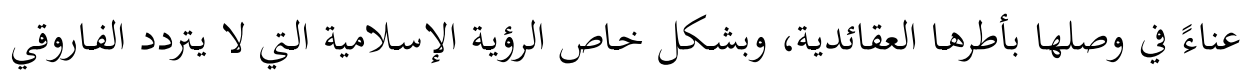

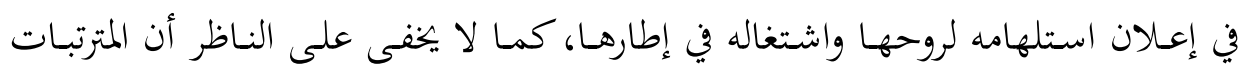

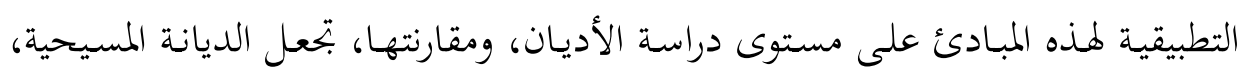


والديانة اليهوديـة في مـأزق كبير، وتبوّء الإسـلام مكانته بوصفه دينـاً يكـترم هـذه المبـادئ

وللتمثيـل على المـآزق التي تواجههـا الديانـة اليهوديـة مـثلاً، ننظـر إلى تطبيـق المبـدأ

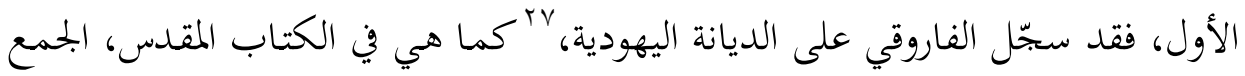

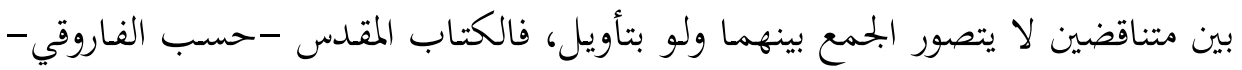

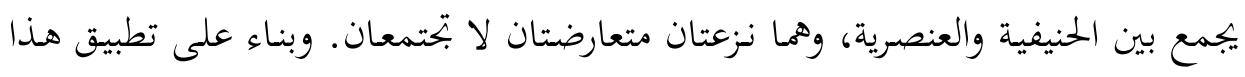

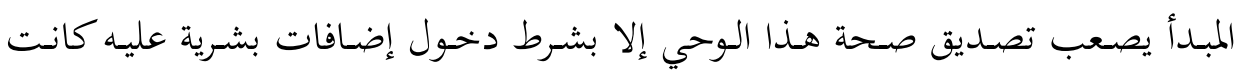

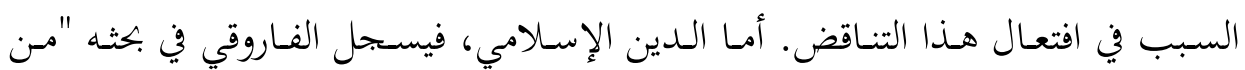

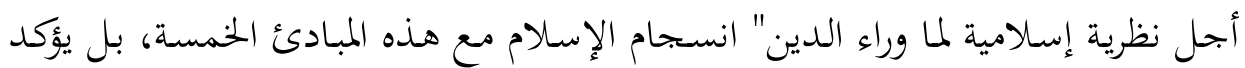

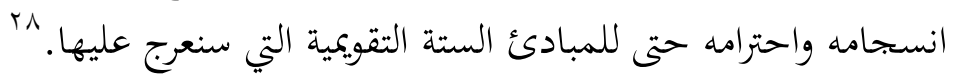

كهـذه المبـادئ النظريـة، أسـس الفـاروقي الإطـار النقـدي لدراسـة الأديـان، وفَفْهِهــا

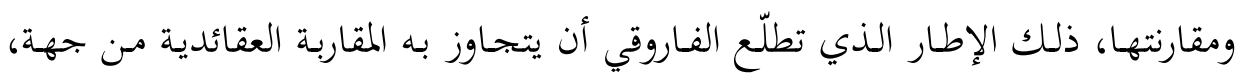

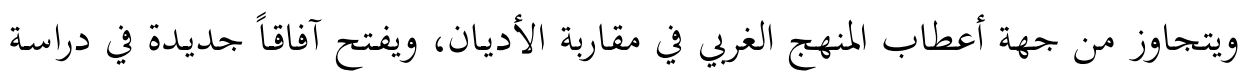
الأديان ونقدها وتقونيمها.

خامساً: النموذج المعرفي لنقد الأديان عند الفاروقي: من الفهم إلى التقويم والنقد إذا كانت المبادئ النظرية تنظم عملية فهم الأديان، وتسـاهم بقدر كبير في نقدها أيضاً، فبإن المبادئ التقويمية وضعها الفاروقي أصلاً لبناء نظرية في نقد الأديان وتقويمها. وعلى النسـق نفسـه في الصسياغة النقديـة البحـردة للمبـادئ النظريـة، فقــ صـاغ الفـاروقي

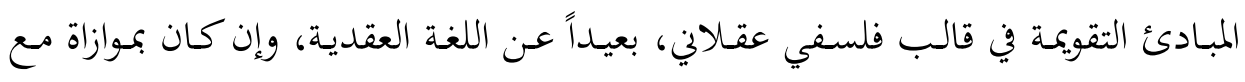
ذلك، فقـد حـاول أن يصـوغها مـن داخل المنظور التوحيـدي الإسـلامي بلغة دينية، وبمـا يناسب مخاطباً آخر غير المخاطب الغربي أو المخاطب الأكاديمي البحتي.

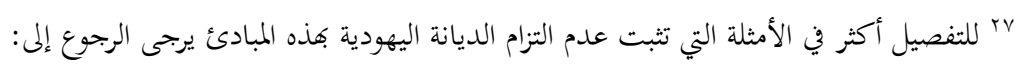

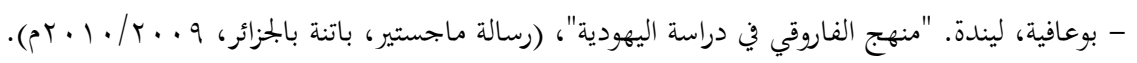

${ }^{28}$ Ismail Al-faruqi, Towards an Islamic theory of meta-religion.... 
ويعـدّ الفـاروقي هـذه القيم بمثابـة المبادئ التي تحـدد الاهتمـام الرئيس للأديـان، التي تشـكل أسـاس جميـع الأديـان والثقافـات، وهـي المبـادئ الـتي تمكّـن مـن قيـاس الأديـان

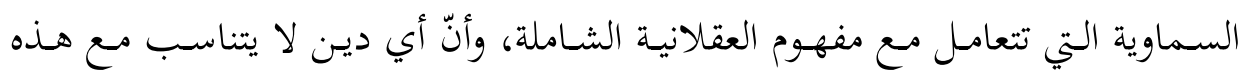

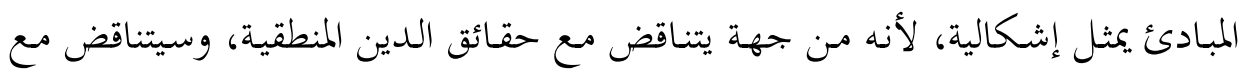
العقلانية المنطقية أيضاً.

\section{المبدأ الأول: العالم عالمان: عالم المثال، والعالم المادي المحسوس:}

الوجود - كما يرى الفاروقي - له مستويان: مثال يمثل القيمة، وواقع محسوس يمثل

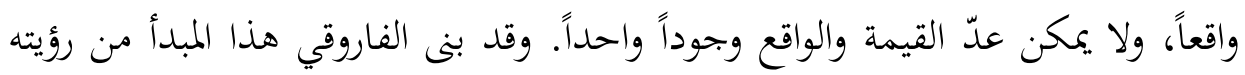
للتوحيد. يقول في كتابه التوحيد ومقتضياته في الفكر والحياة، وجا في شرحه لمبدأ الثنائية:

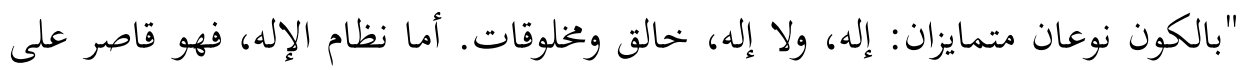
الله سبحانه وتعالى وحده، فهو وحده الرب السرمدى الذى لا بداية له ولا نهاية. وهو

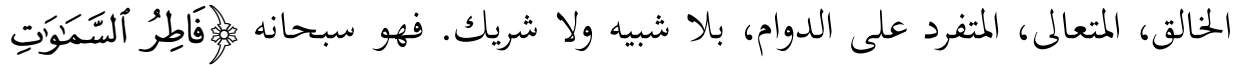

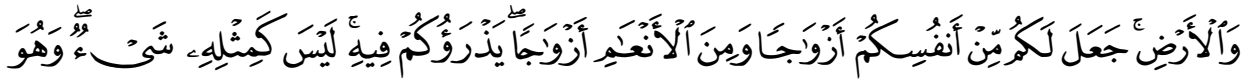

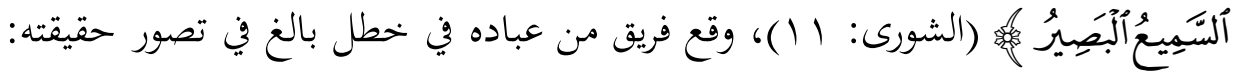

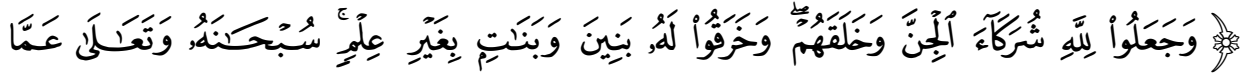

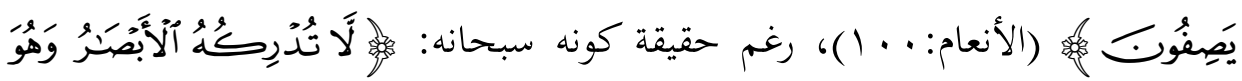

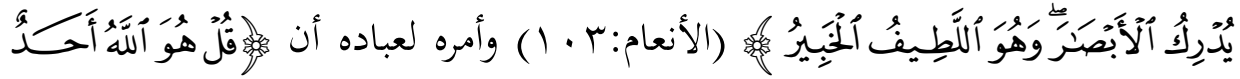

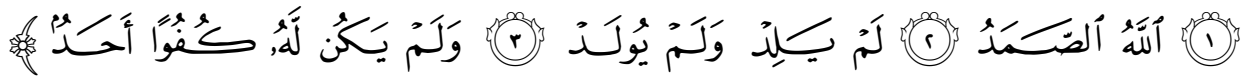
(الإخلاص: 1-؟). وأما النظام الآخر، فيتعلق بالمكان والزمان والخبرة والخليقة، ويشمل كل المخلوقات، وعالم الأشياء والنباتات، والحيوانات، والبشر، والجحن، والملائكة،

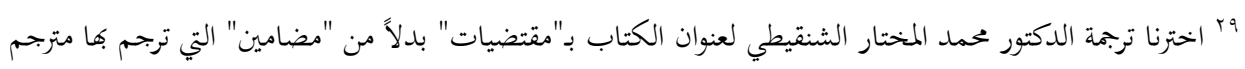

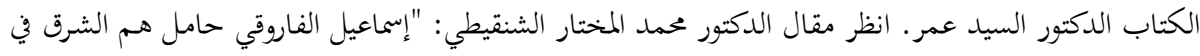
http://www.4nahda.com/node/678 الغرب"، على الرابط: 
والسموات والأرض، والجنة والنار، وكل ما يتعلق بها منذ أن جاءت إلى هذه الحياة وحتى فايتها.

بنـاء على هـا المبـدأ، يرى الفـاروقي أن المسيحية بحـد نفسهـا في مأزق كبير، فوفقاً لمعتقداها، عيسى عليه السلام هو (بشر إلهي) مرسل من قبل الله، فهو في جزء منه إله،

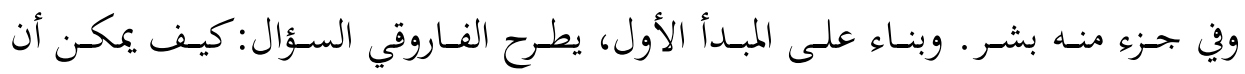

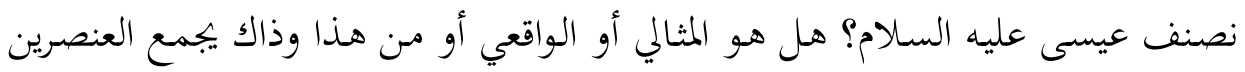

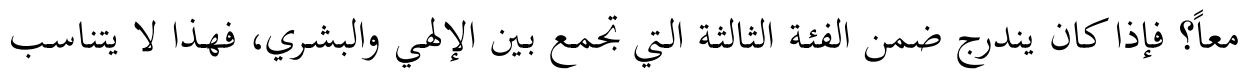

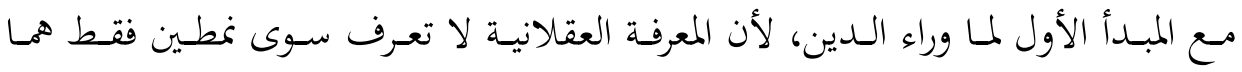

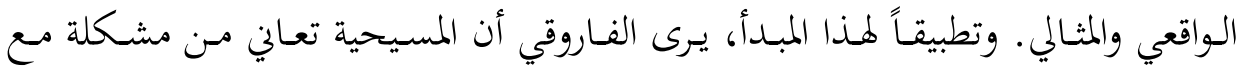

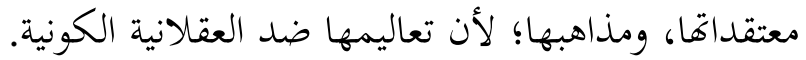

المبدأ الثاني: صلة وارتباط المثال الأعلى بالواقع:

فـالوجود المثـالي مـرتبط بـالوجود الواقعي، والمثـل الأعلى يمـد الوجـود الـواقعي بالمثل والقيم. وهو السبب الفعلي الذي يشكل هوية الوجود الواقعي؛ فالمثل الأعلى هو نموذج

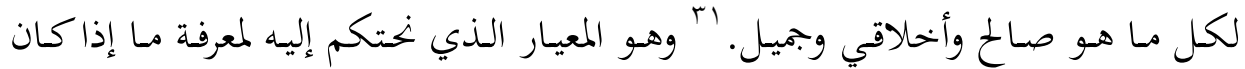
الواقعي الفعلي ذا قيمـة، ويستحيل أن يكون للفعلي معنى مـن دونه، كمـا تستحيل أيّة

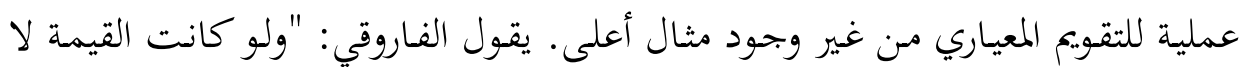

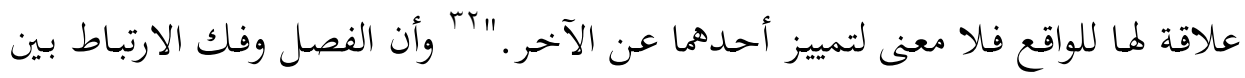
عالم المثال والواقع المحسوس، لا يجعل لعالم المثل دوراً في مواجهة التحديات التي تواجهنا

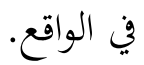

المبدأ الثالث: إن الارتباط بين المثال الأعلى والواقع، الفعلي يتمثل في الأوامر: الفـاروقي وإن كـان يميز داخل المثال الأعلى بـين مـا يسمِّيه المثال الأعلى النظري

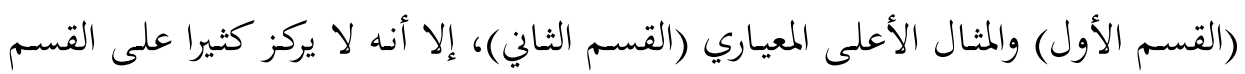

${ }^{31}$ al-Faruqi. Christian Ethics, p. 23.

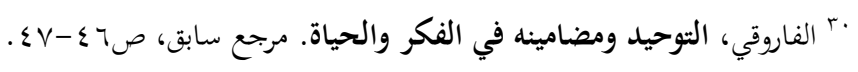
${ }^{32}$ Ibid, p 24. 


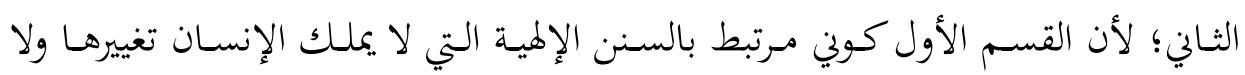

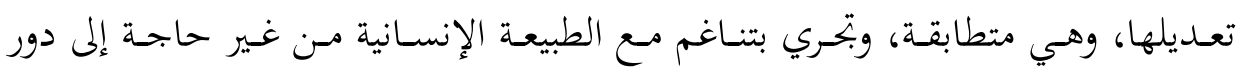

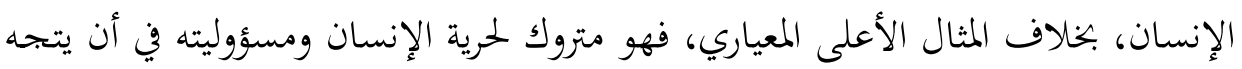

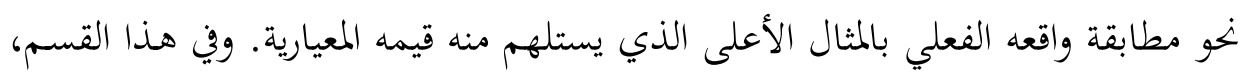

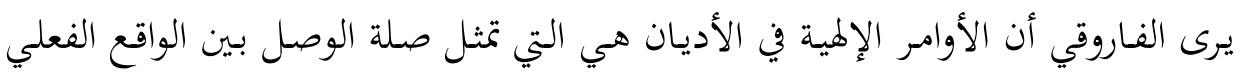

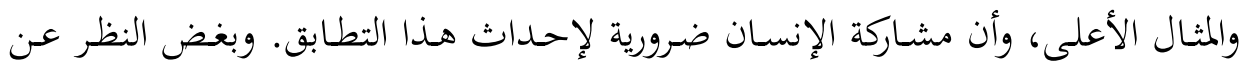

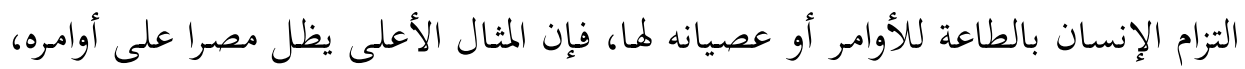

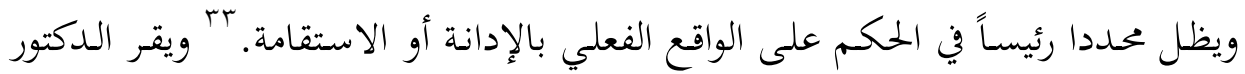

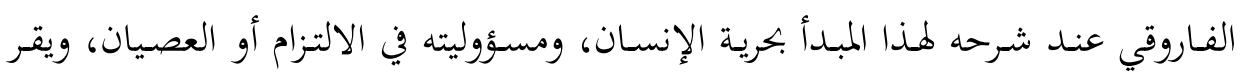

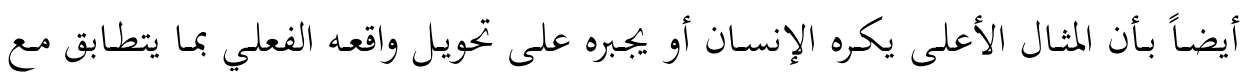

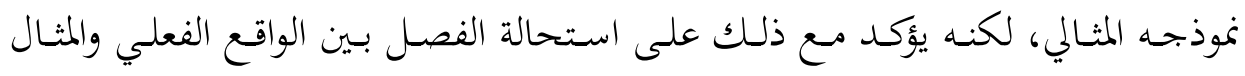

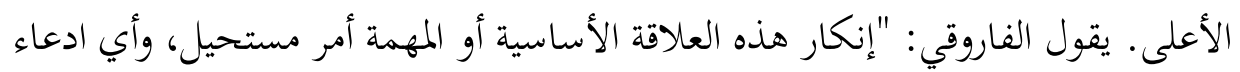

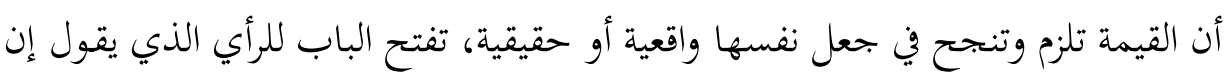

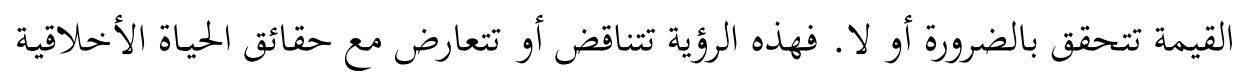

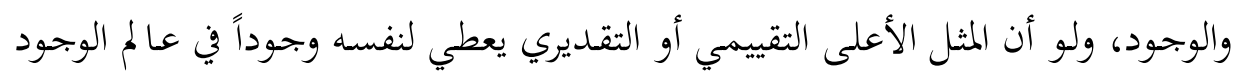

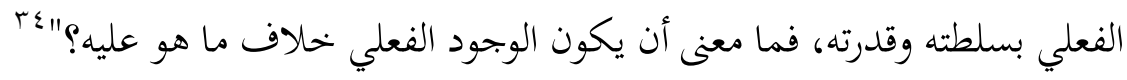

وتأسيساً على هذا المبدأ، يرى الفاروقي أن الوجود الحقيقي هو المثال الأعلى؛ لأنه

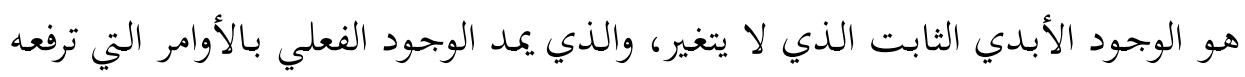
إلى مقاربة المثال الأعلى ومشارفة قيمه ومثله.

$$
\text { المبدأ الرابع: الوجود الفعلي الواقعي في حد ذاته خير: }
$$

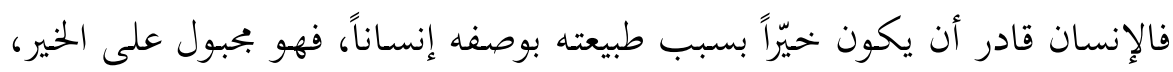

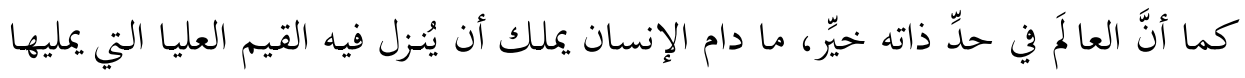

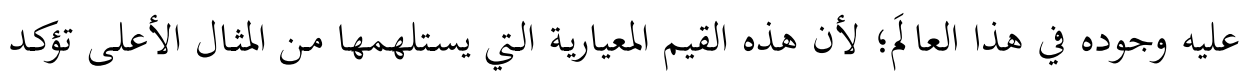

${ }^{33}$ Ibid., p 25.

${ }^{34}$ Ibid., pp 25- 26. 
إنسانيته، وقدرته على تغيير الواقع في الابحاه الذي يتطابق مع المثال الأعلى؛ فالكون من طبيعته منظم ومهيّأ ومستخّر؛ ليعيش فيـه الإنسان، ويبرهن بـالقيم التي تمثّلها مـن المثنال

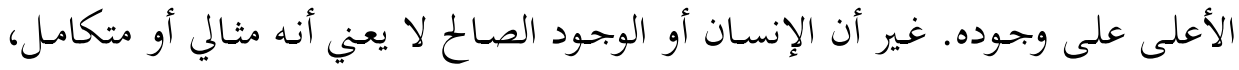

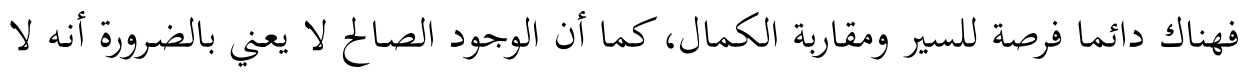
يمكن أن يُصار إلى وضع أفضل منه ما دام الأمر مرتبطاً بقدرة الإنسان على ترجمة وجوده وتسويغه من خلال العمل الصالح، وتنزيل القيم المعيارية على أرض الواقع. قد لا تبدو الصلة واضحة بين هذا المبدأ والأديان؛ لأهـا ربمـا تكون أكثر وضوحاً

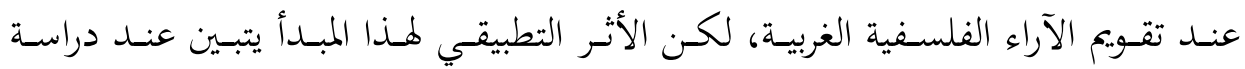

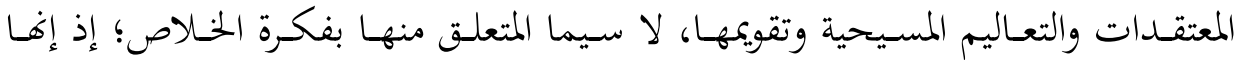
تستبطن رؤية سلبية عدمية للخليقة؛ إذ ترى أهـا آثمة، وأن طريق خلاصها يمرّ بالضرورة من الإيمان بالمسيح المخلّص، وهي رؤية تتناقض مع المبدأ الذي وضعه الفاروقي، وجعله من المبادئ الأساسية في تقويم الأديان، وبيان نسبة انتسابها إلى الدين الحقية لهيقي. المبدأ الخامس: الوجود الفِعلي المَرن، ويقبل إعادة التشكيل:roro ملخص هذا المبـدأ أن الإنسـان يمكن أن يعدِّل الواقع، ويضفي عليه قيماً جديدة،

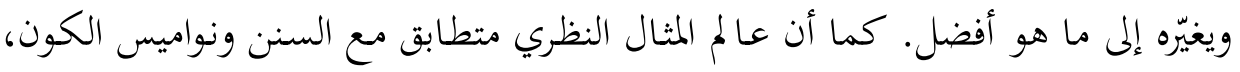

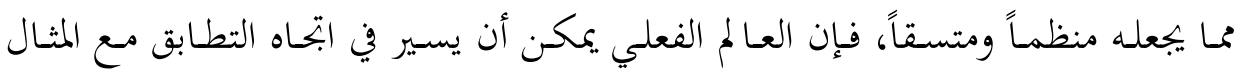

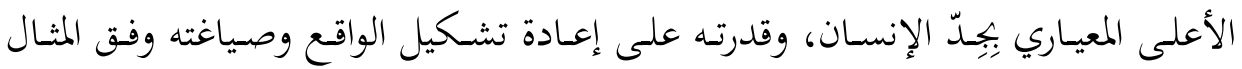

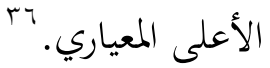

${ }^{35}$ Ibid., p. 31.

${ }^{36}$ Ibid, p. 29.

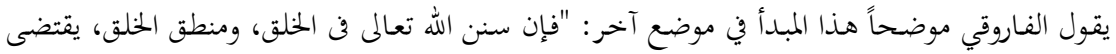

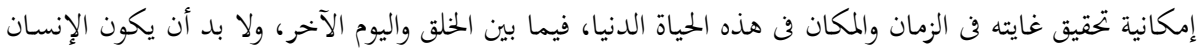

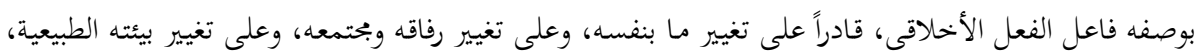

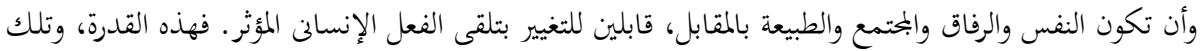

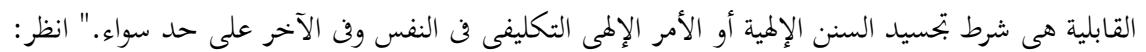

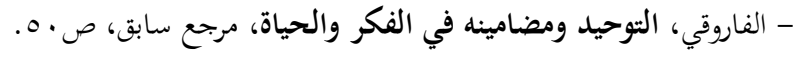


المبدأ السادس: الكمال في الكون مسؤولية وعبء على الإنسان:

وهو تكملة للمبادئ الخمسة؛ إذ يترتب على المبدأ الخامس "إعادة تشكيل الواقع" لمكي

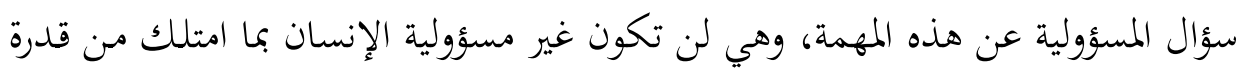
اكتسبها من مسوّغ وجوده، وبما تمثل من قيم استلهمها من المثنال الأعلى المعياري.

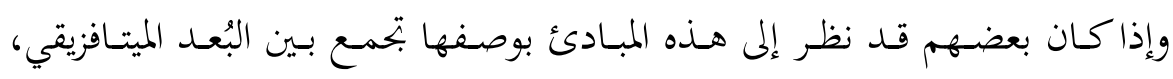

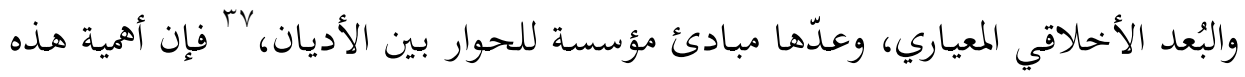

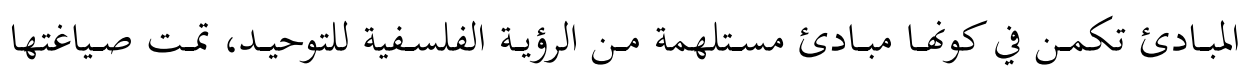

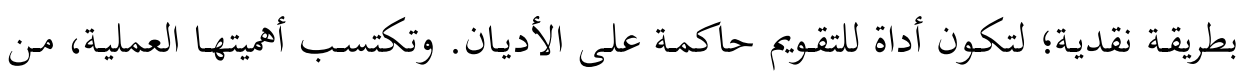

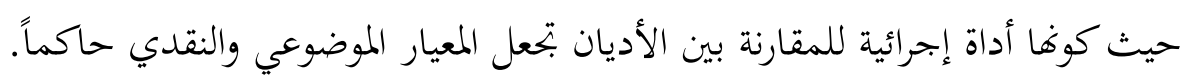
ولا شك في أن بعض الباحثين الأكاديميين الغربيين، لا سيّما في حقل علم الأديان،

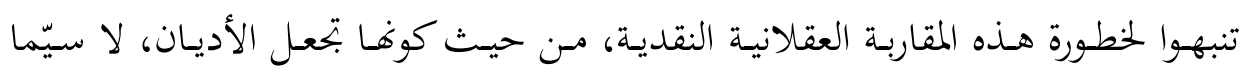

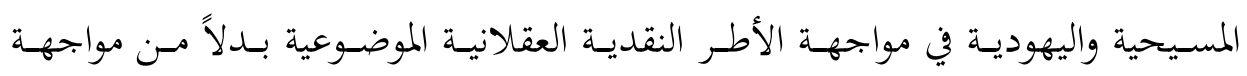

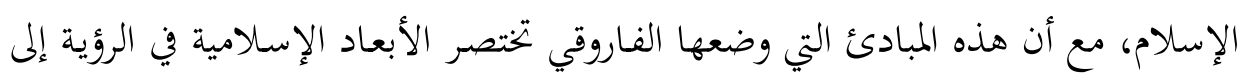

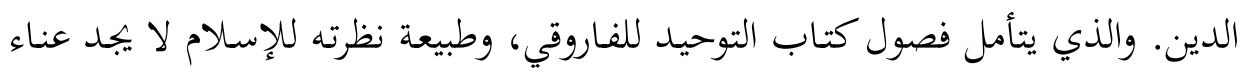

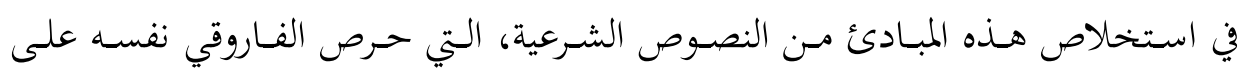

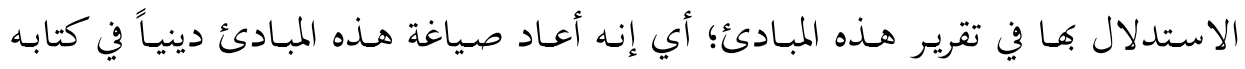

$$
\text { (التوحيد) لمخاطَب آخر هو القارئ المسلم. }
$$

وتكمن أهمية هذا المنهج المتفرد الذي نسجه الفاروقي، أو قل، هذا النموذج المعريف

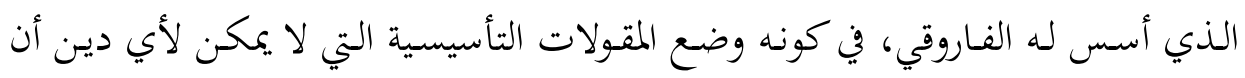

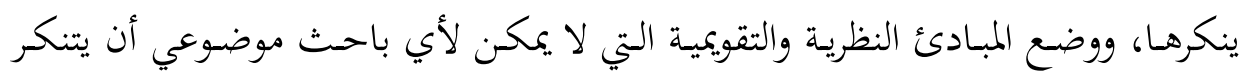

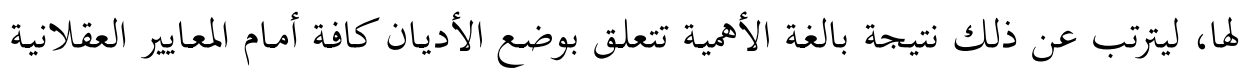
rv صهيب، مصطفى طه. الحوار الإسلامي المسيحي في السودان أسس معرفية ومعضلات تاريخية، على الرابط

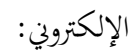

http://fikria.org/articles/article_view.php?id=105 


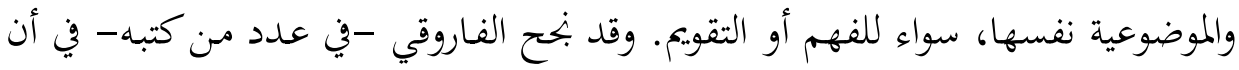

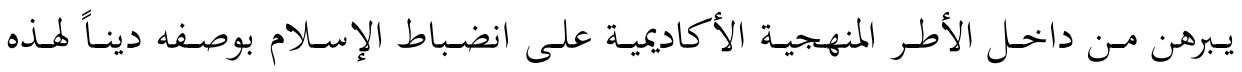

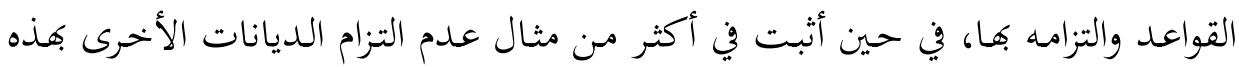

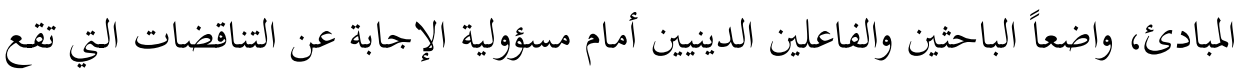

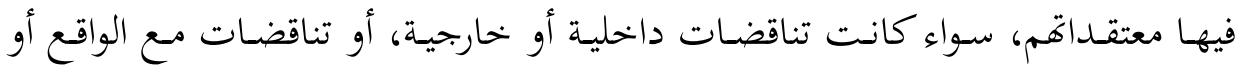

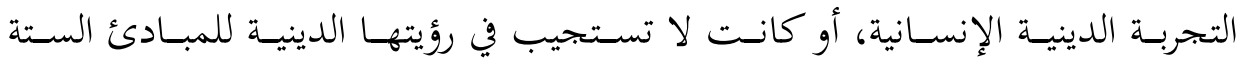

سادساً: في العلاقة بين النموذج المعرفي لنقد الأديان، والنمط المثالي لدراستها

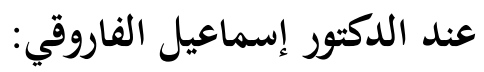

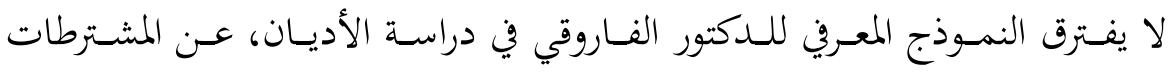

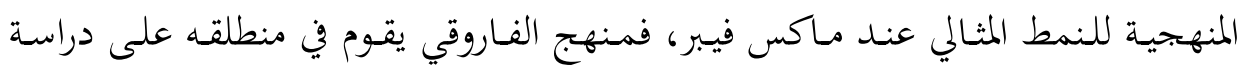

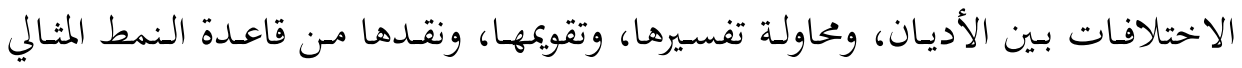

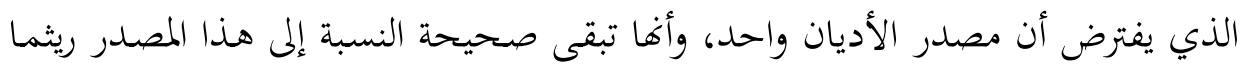

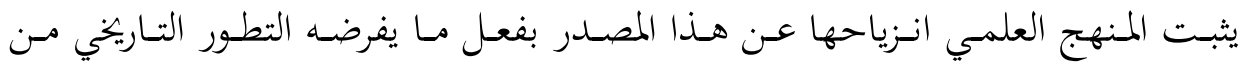

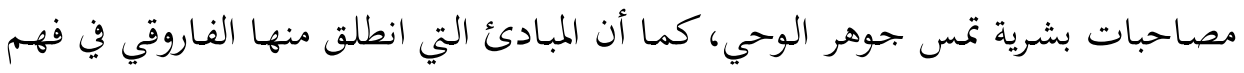

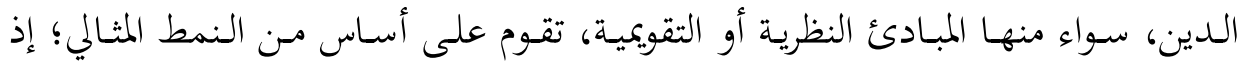

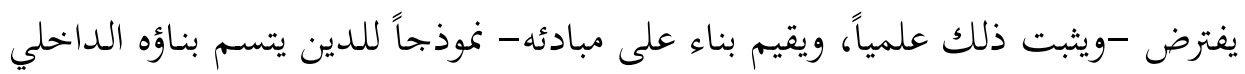

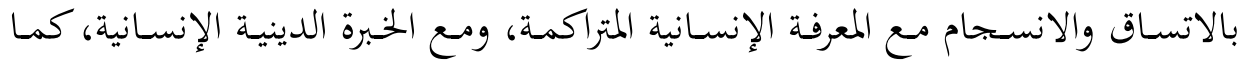

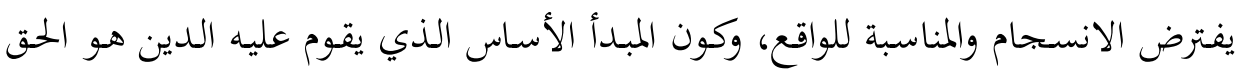

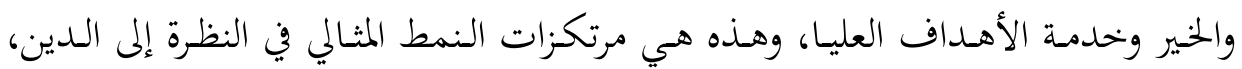

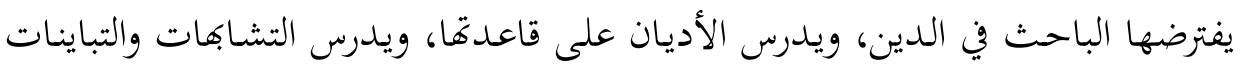

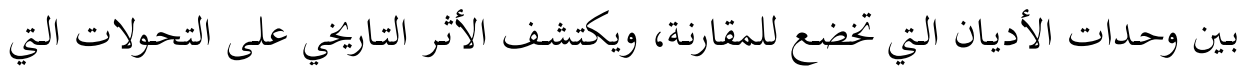

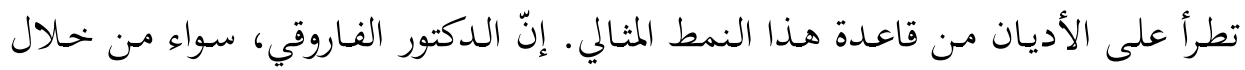

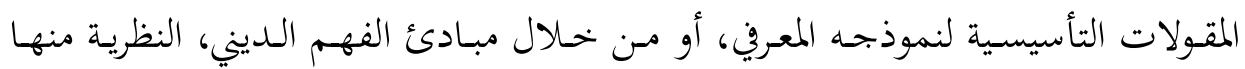


والتقويمية، قد وضع الأساسيات للنمط المثالي، ليس فقط في دراسة الدين وفهمه، وإنما

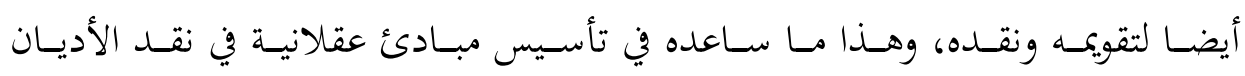

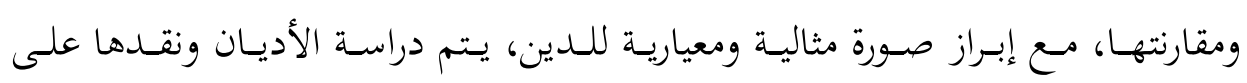
مقاسها.

ومما يؤكد أهمية هذا النمط المثالي الافتراضي في دراسة الدين وفهمه ونقده، أنه لا

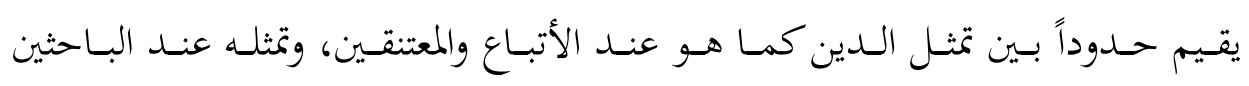

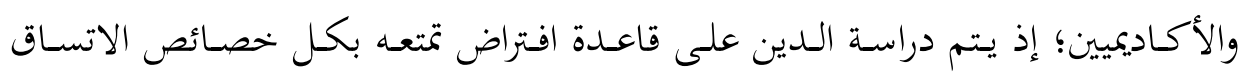

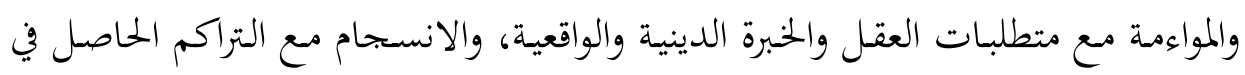

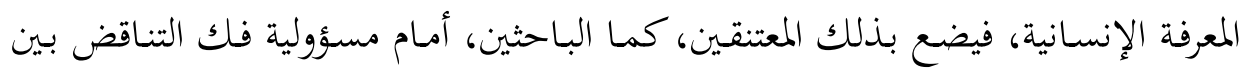

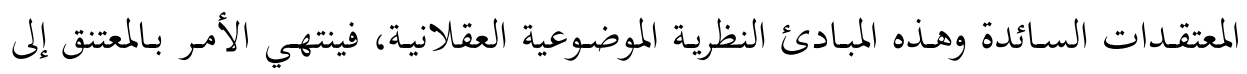

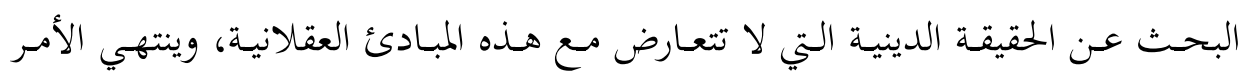

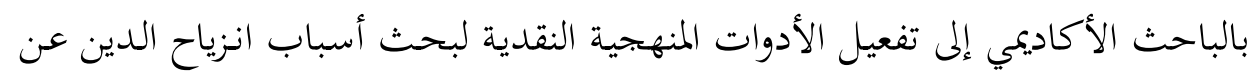
المبادئ النظرية والتقويمية، التي تمثل قاعدة النمط المثالي في النظرة إلى الدين. ومما يؤكد أهمية، بل خطورة هذا المسلك العقلاني في النظرة إلى الدين، أن أطروحة

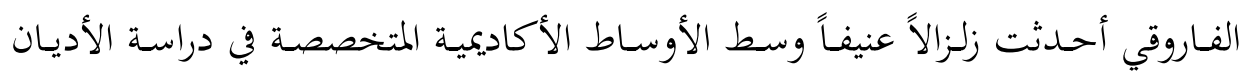
ومقارنتها خاصة منها المسيحية؛ إذ نقل الحوار الديني من بُعده الديني إلى إطاره العقلاني

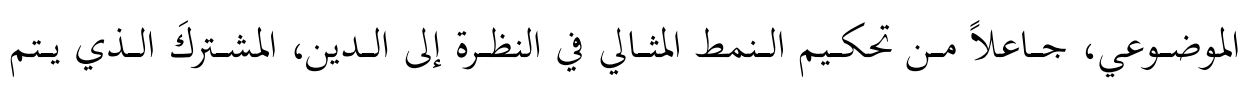

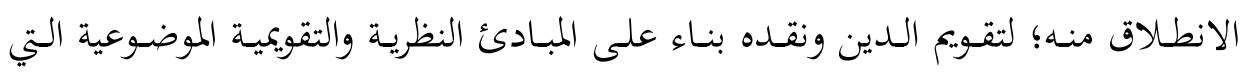
تبناها في نموذجه المعريز.

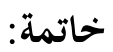

من المؤكد أننا لم نستوف النموذج المعريف لنقد الأديان عند الفاروقي حقه، ولم نأت

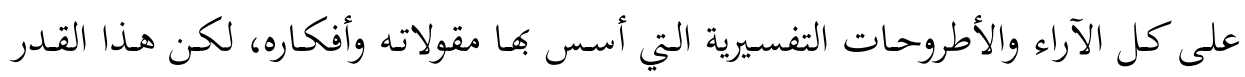


اليسير الذي وقفنا عليه من كتبه يسعفنا في الانتهاء إلى جملة من الخلاصات المهمة التي

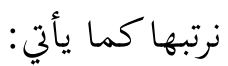

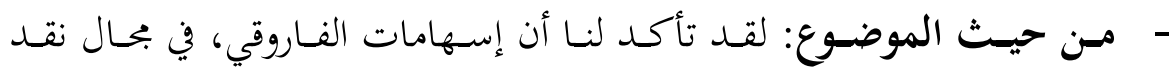

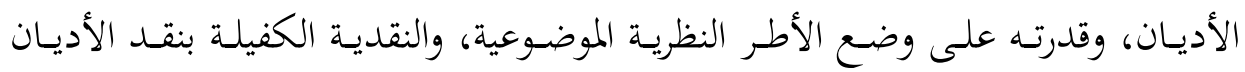

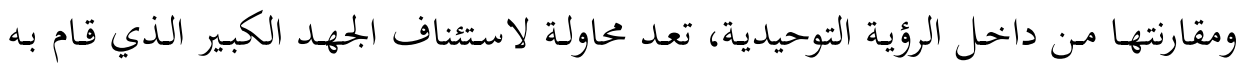

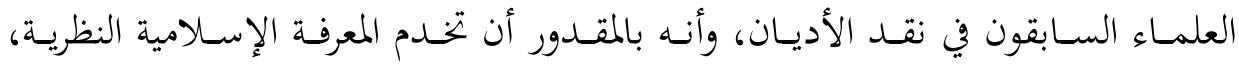

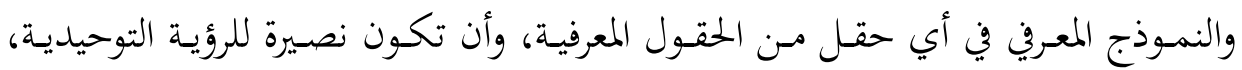
ومساهمة في التراكم المعري،، ومحققة النضج المطلوب في المناهج والنماذج التفسيرية. كما تأكد بأن إخلاء التخصصات المعرفية من المساهمة الإسلامية، لا يترتب عنه إلا مزيد من ون الغزوات المعرفية الغربية التي يصعب مواجهتها مس غير جهـد معرفي استثنائي في الفهـم والنقد، ثم التجاوز والتنظير، وإبداع النموذج المعريف المؤطر بالرؤية الإسلامية. - من حيث المنهج: لقد قدمت كتابات الفاروقي نموذجاً للقدرة على نقل الأطر المرجعية إلى مناهج، ومعايير عقلانية، وموضوعية نقدية، يمكن الاحتكام إليها في مختلف

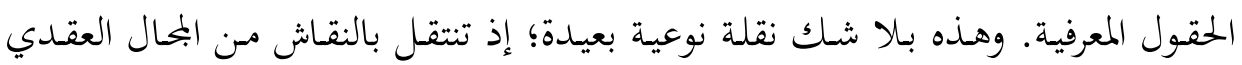
إلى المحال العلمي الموضوعي، وبتعل الآخر في مواجهة العقلانية والموضوعية بدل مواجهة الذات، وهو متجه نوعي كان يرجى أن يتم النسج عليه في مختلف فروع المعرفة، لا سيّما تلك المعرفة التي تنتجها العلوم الاجتماعية.

وعلى الرغم مـن بعض الانتقـادات التي أُحـذت على الفـاروقي أنه سقط في المزالق نفسها التي انتقد عليها الباحثين الغربين المسيحيين، وذلك حين صاغ المعايير العلمية التي

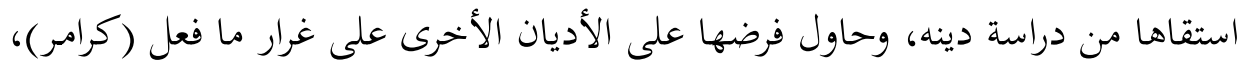

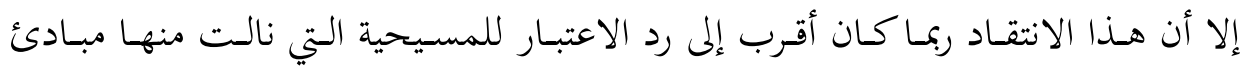


الفـاروقي كثيراً، ووضعت البـاحثين خاصـة المسيحيين أمـام تحـدي النزول عند مسوّغات الموضوعية، والعقلانية في تقويم المسيحية. ${ }^{\top}$

- من حيث المترتبات العملية: فإذا كان الحل التطبيقي القريب من هذا الموضوع

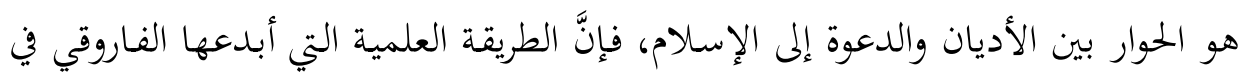
تقويم الأديان تعدّ أداة قوية وناجعة في التمكين لقيم الإسلام، ومحاجحة أنصار الأديان الأخرى، وتحويل حوار الأديان إلى كسب إسلامي محض بعد أندان أن أصبح يستثمر سياسيا مع إفراغ مضمونه من أي محتوى معريف علمي.

- من حيـث الآفاق المفتوحة: يمكـن استخلاص نتيجة مهمة، وهي أن جهود الفاروقي، تفتح آفاقاً واعدة ليس فقط لأسلمة المعرفة، وتقديم النموذج المعري الإسلامي

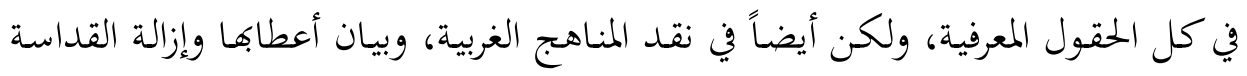

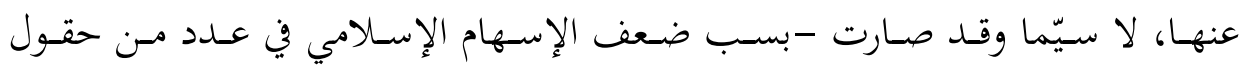
المعرفة- تشكل اليوم في العالم العربي والإسلامي أدوات مقدسة لا سبيل إلى الطعن فيها.

^^r حاول عدد من القساوسة في جامعة ماكجيل التي كتب الفاروقي الكتاب في رحابها أن يمنعوا نشره، قائلين "إنه يزلزل الإيمان المسيحي في قلوب قرائه". انظر:

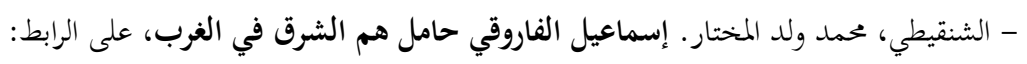
http://www.4nahda.com/node/678 